\title{
POM@MOF Hybrids: Synthesis and Applications
}

\author{
Jiamin Sun ${ }^{1}$, Sara Abednatanzi ${ }^{1}{ }^{1}$, Pascal Van Der Voort ${ }^{1, *} \mathbb{C}$, Ying-Ya Liu ${ }^{2}$ and Karen Leus ${ }^{1}$ \\ 1 COMOC-Center for Ordered Materials, Organometallics and Catalysis, Department of Chemistry, \\ Ghent University, Krijgslaan 281, Building S3, 9000 Ghent, Belgium; jiamin.sun@ugent.be (J.S.); \\ sara.abednatanzi@ugent.be (S.A.); Karen.Leus@ugent.be (K.L.) \\ 2 State Key Laboratory of Fine Chemicals, School of Chemical Engineering, Dalian University of Technology, \\ Dalian 116024, China; yingya.liu@dlut.edu.cn \\ * Correspondence: pascal.vandervoort@ugent.be; Tel.: +32-(0)9-264-44-42
}

Received: 4 May 2020; Accepted: 19 May 2020; Published: 21 May 2020

\begin{abstract}
The hybrid materials that are created by supporting or incorporating polyoxometalates (POMs) into/onto metal-organic frameworks (MOFs) have a unique set of properties. They combine the strong acidity, oxygen-rich surface, and redox capability of POMs, while overcoming their drawbacks, such as difficult handling, a low surface area, and a high solubility. MOFs are ideal hosts because of their high surface area, long-range ordered structure, and high tunability in terms of the pore size and channels. In some cases, MOFs add an extra dimension to the functionality of hybrids. This review summarizes the recent developments in the field of POM@MOF hybrids. The most common applied synthesis strategies are discussed, together with major applications, such as their use in catalysis (organocatalysis, electrocatalysis, and photocatalysis). The more than 100 papers on this topic have been systematically summarized in a handy table, which covers almost all of the work conducted in this field up to now.
\end{abstract}

Keywords: metal-organic frameworks; polyoxometalates; hybrid materials; synthesis; catalysis

\section{Introduction}

Polyoxometalates (POMs), a class of metal oxide clustered anions, have already been investigated for more than 200 years. Their history dates back to 1826, when Berzelius reported the discovery of the first $\mathrm{POM}$ cluster $\left(\mathrm{NH}_{4}\right)_{3}\left[\mathrm{PMo}_{12} \mathrm{O}_{40}\right] \mathrm{nH}_{2} \mathrm{O}$ [1]. However, due to difficulties achieving insights into the $\mathrm{POM}$ structure, no significant progress was made until Keggin determined the structure of $\mathrm{H}_{3} \mathrm{PW}_{12} \mathrm{O}_{40}$ in 1934 [2]. Since then, the interest of scientists in POMs has increased drastically, not only in the development of new POM structures, but also towards their use in various applications, such as catalysis, optics, magnetism, biological medicine, environmental science, life science, and technology [3-7]. In particular, their use in catalysis is one of the most examined fields because of their strong acidity, oxygen-rich surface, photoactivity, and redox capability. Despite these interesting characteristics, POMs still exhibit some drawbacks for their use in catalysis. First, POMs possess a low surface area $\left(<10 \mathrm{~m}^{2} \mathrm{~g}^{-1}\right)$, which consequently hinders the accessibility of reactants and secondly, their high solubility in aqueous solutions and polar organic solvents results in a low recyclability [4]. The immobilization of POMs into/onto porous solids has been proposed to overcome these shortcomings and to achieve catalysts with a high catalytic performance. In the past few decades, many porous materials have been examined as supports for the immobilization of POMs, e.g., silica, ion-exchange resin, zeolites, and activated carbon [5-8]. Since the discovery of metal-organic frameworks (MOFs), much effort has been dedicated to use these porous materials as potential supports for POMs. MOFs are inorganic-organic hybrid crystalline materials that are constructed from metal ions or clusters and organic linkers through coordination bonds. These materials have attracted considerable interest in recent years due to their large surface areas, tunable pore size, and designable functionalities. 
So far, MOFs have shown great potential in gas storage and separation, catalysis, sensing, drug delivery, proton conductivity, solar cells, supercapacitors, and biomedicine [8-13]. Moreover, MOFs are regarded as an outstanding platform for introducing guest molecules because of the high accessibility of their internal surface area and long-range ordered channels. So far, several active sites have been successfully embedded in the pores or cages of MOFs, such as noble metals, metal oxides, enzymes, and POMs [14-17].

The first report of a POM@MOF hybrid was reported in 2005 by Férey and co-workers [18]. In this seminal work, the $\mathrm{POM}, \mathrm{K}_{7} \mathrm{PW}_{11} \mathrm{O}_{39}$ (van der Waals radius, $13.1 \AA$ ), was successfully encapsulated into the big cages of the highly stable Cr-based MOF, MIL-101, by using an impregnation method. To date, several other thermal and chemical stable MOFs have been applied as supports to host POMs for their use in catalysis, including MIL, UiO, ZIF series, NU-1000, and Cu-BTC frameworks (see Table 1). The most examined POMs that have been encapsulated into MOFs are the well-known Keggin $\left[\mathrm{XM}_{12} \mathrm{O}_{40}\right]^{\mathrm{n}-}$ and Dawson $\left[\mathrm{X}_{2} \mathrm{M}_{18} \mathrm{O}_{62}\right]^{\mathrm{n}-}(\mathrm{X}=\mathrm{Si}, \mathrm{P}, \mathrm{V}, \mathrm{Bi}$, etc.; $\mathrm{M}=\mathrm{V}, \mathrm{Mo}$, W, etc. $)$ POMs and their derivatives. These POMs are of significant interest because their structure and properties can be easily varied by removing one or more $\mathrm{MO}^{4+}$ units, leading to lacunary $\mathrm{POMs}$ such as $\left[\mathrm{PW}_{9} \mathrm{O}_{34}\right]^{9-}$, or by the substitution of $\mathrm{X}$ and $\mathrm{M}$ by different metals or a combination of two fragments of the Keggin structure, leading to sandwich-type POMs such as $\left[\mathrm{Tb}\left(\mathrm{PW}_{11} \mathrm{O}_{39}\right)_{2}\right]^{11-}$.

There are several advantages of using MOFs as a host matrix to encapsulate POMs. First of all, their exceptionally high surface areas and confined cages/channels make it possible to ensure a homogeneous distribution of the POM in the MOF host. This not only prevents the agglomeration of POMs, but also improves their stability and recyclability and ensures a fast diffusion of substrates and products. Secondly, the highly regular cages and windows of MOFs ensure a high substrate selectivity, or, in other words, only specific substrates/products are able to reach the active POM sites. Thirdly, owing to the good interaction and electron transfer between the MOF and POM, an increased synergistic catalytic performance is typically observed. Finally, the chemical environment of POMs can easily be adjusted through modification or functionalization of MOFs. Therefore, POM@MOF hybrids not only combine the interesting properties of POMs and MOFs, but also allow the aforementioned disadvantages of POMs to be tackled to afford synergistic catalysis. This review is focused on the synthetic aspects of POM@MOF hybrids, as well as their use in catalysis (organocatalysis, electrocatalysis, and photocatalysis). Alongside the POM@MOF systems discussed here, where the POMs are encapsulated inside a MOF host, POM-based MOFs have also been investigated. In these MOFs, the POMs form the actual metal nodes that are interconnected by organic linkers [19-21]. However, these fall outside the scope of this review.

Table 1. Physical properties of representative metal-organic frameworks (MOFs) used to encapsulate polyoxometalates (POMs) for catalysis.

\begin{tabular}{|c|c|c|c|c|c|}
\hline MOFs & Chemical Formula & Window & Porosity & BET $/ \mathrm{cm}^{3} \mathrm{~g}^{-1}$ & Ref. \\
\hline UiO-66 & $\begin{array}{c}\mathrm{Zr}_{6} \mathrm{O}_{4}(\mathrm{OH})_{4}(\mathrm{BDC})_{6}, \mathrm{BDC}= \\
\text { 1,4-benzenedicarboxylate }\end{array}$ & $6 \AA$ triangular & $\begin{array}{c}12 \AA \text { (octahedral cages) and } \\
7.5 \AA \text { (tetrahedral cages) }\end{array}$ & 1100-2000 & [22] \\
\hline UiO-67 & $\begin{array}{c}\mathrm{Zr}_{6} \mathrm{O}_{4}(\mathrm{OH})_{4}(\mathrm{BPDC})_{6}, \mathrm{BPDC}= \\
\text { biphenyl-4,4'-dicarboxylate }\end{array}$ & $8 \AA$ triangular & $\begin{array}{c}16 \AA \text { (octahedral cages) and } 12 \\
\AA \text { A (tetrahedral cages) }\end{array}$ & $2100-2900$ & [23] \\
\hline NU-1000 & $\begin{array}{c}\mathrm{Zr}_{6} \mathrm{O}_{4}(\mathrm{OH})_{4}\left(\mathrm{H}_{2} \mathrm{O}\right)_{4}(\mathrm{OH})_{4}(\mathrm{TBAPy})_{2} \\
\text { TBAPy }=1,3,6,8- \\
\text { tetrakis(p-benzoate)pyrene) }\end{array}$ & $10 \AA ̊$ orthogonal & $\begin{array}{l}31 \AA \text { (hexagonal channels) and } \\
12 \AA \text { (triangular channels) }\end{array}$ & 900-2000 & [24] \\
\hline MOF-545 & $\begin{array}{c}\mathrm{Zr}_{6} \mathrm{O}_{8}\left(\mathrm{H}_{2} \mathrm{O}\right)_{8}\left(\mathrm{TCPP}-\mathrm{H}_{2}\right)_{2}, \mathrm{TCPP}= \\
\text { tetrakis }(4 \text {-carboxyphenyl)porphyrin }\end{array}$ & - & $\sim 16 \AA$ and $36 \AA$ & $1900-2500$ & [25] \\
\hline ZIF-8/67 & $\begin{array}{c}\mathrm{Zn}(\mathrm{MeIM})_{2} / \mathrm{Co}(\mathrm{MeIM})_{2} \\
\text { MeIM = imidazolate-2-methyl }\end{array}$ & 3.4 Å hexagonal & $\sim 12 \AA$ & 1000-1800 & [26] \\
\hline MIL-101 & $\begin{array}{c}\mathrm{X}_{3}(\mathrm{~F}) \mathrm{O}(\mathrm{BDC})_{3}\left(\mathrm{H}_{2} \mathrm{O}\right)_{2},(\mathrm{X}=\mathrm{Cr}, \mathrm{Al}, \mathrm{Fe}) \\
\mathrm{BDC}=1,4 \text {-benzenedicarboxylate })\end{array}$ & 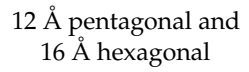 & $\sim 29 \AA$ and $34 \AA$ & $2500-4500$ & [18] \\
\hline MIL-100 & $\begin{array}{c}\mathrm{Fe}_{3} \mathrm{FO}\left(\mathrm{H}_{2} \mathrm{O}\right)_{2}(\mathrm{BTC})_{3} \mathrm{BTC}= \\
\text { 1,3,5-benzenetricarboxylat }\end{array}$ & $\sim 5.5 \AA$ and $8.6 \AA$ & $25 \AA ̊$ and $29 \AA$ & $1500-3000$ & [27] \\
\hline $\mathrm{Cu}$-BTC & $\mathrm{Cu}_{3}(\mathrm{BTC})_{2}$ & $\sim 9 \AA$ and $4.6 \AA$ & $10-13 \AA$ & 1000-1500 & [28] \\
\hline
\end{tabular}




\section{Synthesis and Design of POM@MOF}

To date, several well-known highly stable MOFs have been used to encapsulate POMs, including MIL, UiO, and ZIF series, as well as NU-1000 and Cu-BTC frameworks. One of the most commonly applied methods to embed POMs in MOFs is impregnation. Wet impregnation is a simple and straightforward method, since most of the POMs are well-soluble in polar solvents. Typically, the activated MOF powder is immersed in the POM solution to obtain the composite material. Several POM@MOF hybrids have been successfully synthesized through this wet impregnation method, such as POM@MIL, POM@ZIF, and POM@UN-1000. An important aspect allowing the use of this method is that the size of the POM must be smaller than the windows of the MOF. Moreover, for some POMs and MOFs, it was observed that the POM loading could not be enhanced by increasing the concentration of POM in aqueous solution when a certain POM loading was achieved. For example, for POMs whose size is bigger than the pentagonal windows (12 $⿱$ A) of MIL-101(Cr), the POMs were only encapsulated into the large cages, while the other cages, which represent $2 / 3$ of the total number of cages of MIL-101(Cr), were unfilled. Naseri et al. demonstrated that the loading of a sandwich-type POM $\left[(\mathrm{HOSnOH})_{3}\left(\mathrm{PW}_{9} \mathrm{O}_{34}\right)_{2}\right]^{12-}(15.2 \AA \times 10.4 \AA)$ could not be enhanced by increasing the concentration of $\mathrm{POM}$ in the aqueous solution [29].

The impregnation method cannot be used for MOFs whose window size is smaller than the POMs, e.g., $\mathrm{Cu}-\mathrm{BTC}, \mathrm{UiO}$, and ZIF. Therefore, for these MOFs, the one-pot (also known as bottle-around-the-ship) synthesis method has been applied to obtain POM@MOF hybrids. The one-pot method is also often used to obtain POM-encapsulated MOFs in which the anionic form of the POM acts as a structure directing agent to ensure deprotonation of the organic carboxylate ligand. For the preparation of POM@MOF hybrids, typically, the synthesis parameters employed to obtain the parent MOF are used upon addition of the POM. The one-pot method can not only be used to synthesize POM@MOFs that cannot be obtained by impregnation, but can also confine the POMs in the MOF cages to prevent leaching if the size of the POMs is bigger than the windows of the MOFs.

Therefore, in conclusion, the synthesis approaches commonly used to incorporate POMs into MOFs are impregnation and one-pot synthesis. To choose, however, the "correct" methodology, two questions need to be addressed in advance: does the size of the POM fit into the MOF cages and can the pore window of the MOF confine the POM? If both criteria are met, one can expect that the obtained catalyst will work efficiently at a molecular level.

As was mentioned before, the first report on the embedding of a POM into the cages of an MOF was reported by Férey's group. They showed that a Keggin-type POM, $\mathrm{K}_{7} \mathrm{PW}_{11} \mathrm{O}_{40}$ (van der Waals radius, 13.1 A), can be confined in MIL-101(Cr) by simple impregnation. The resulting MIL-101-Keggin solid was characterized by XRD, TGA, and $\mathrm{N}_{2}$ sorption, as well as IR and ${ }^{31} \mathrm{P}$ solid state $\mathrm{NMR}$, which confirmed the presence of Keggin ions within the pores [18]. As summarized in Table 1, MIL-101 has two types of mesoporous cages: a smaller one with an inner size of $\sim 29 \AA$ and pentagonal windows of $\sim 12 \AA$, and a larger one with an inner size of $\sim 34 \AA$ and hexagonal windows of $\sim 15 \AA$. Based on the size of the cage windows and the size of the POM, one can conclude that the POM can only diffuse into the largest cages.

In 2010, Gascon and co-workers prepared PW $12 @ \mathrm{MIL}-101\left(\mathrm{PW}_{12}=\left[\mathrm{PW}_{12} \mathrm{O}_{40}\right]^{3-}\right)$ composites by using a one-pot and wet impregnation method [30]. The authors observed a homogeneous distribution of $\mathrm{PW}_{12}$ when the one-pot synthesis was applied under stirring conditions. By using the wet impregnation method, high loadings of $\mathrm{PW}_{12}$ in MIL-101 resulted in a drastic decrease in the surface area and pore volume. However, this decrease in surface area and pore volume was smaller for the one-pot synthesis method in comparison to the impregnation method using the same $\mathrm{PW}_{12}$ loading. The authors stated that in the one-pot synthesis, both the large- and medium-sized cavities were occupied, while, when using the impregnation method, only the larger cavities were accessible.

Canioni and co-workers compared different synthesis methods for encapsulating POMs in MIL-100(Fe) [31]. The authors observed a good agreement between the experimentally obtained POM loading and the maximum theoretical loading for the PMo $\mathrm{PM}_{12} @ \mathrm{MIL}-100\left(\mathrm{PMo}_{12}=\left[\mathrm{PMo}_{12} \mathrm{O}_{40}\right]^{3-}\right)$ obtained by a one-pot solvothermal synthesis. In addition to this, the solvothermally obtained 
$\mathrm{PMo}_{12} @$ MIL-100 showed a good stability in aqueous solution and no POM leaching was observed after 2 months. On the contrary, the PMo $\mathrm{PM}_{12} @$ MIL-100 material prepared through impregnation exhibited significant POM leaching after 2 months.

Based on the above examples, POM leaching was observed for the POM@MIL-101 and POM@MIL-100 obtained by impregnation, since immobilization is based on an adsorption equilibrium. One way to circumvent this leaching is to use amino-functionalized MOF structures, e.g., $\mathrm{UiO}-66-\mathrm{NH}_{2}$ and MIL-53- $\mathrm{NH}_{2}$, which can ensure a better interaction with the polyanions [32-34]. The formation of complexes such as $-\mathrm{NH}_{3}{ }^{+}\left[\mathrm{H}_{2} \mathrm{PW}_{12} \mathrm{O}_{40}\right]^{-}$between primary amines, ammonia, or pyridine and $\mathrm{PW}_{12}$ is well-documented [35]. In 2012, Gascon and co-workers used a microwave-assisted one-pot synthesis to obtain $\mathrm{PW}_{12} @ \mathrm{MIL}-101-\mathrm{NH}_{2}(\mathrm{Al})$ as their attempts to synthesize MIL-101- $\mathrm{NH}_{2}(\mathrm{Al})$ containing PW 12 by one-pot solvothermal synthesis were not successful [36]. One year later, Bromberg et al. examined the encapsulation of POMs in amino-functionalized MOFs ( $\mathrm{NH}_{2}-\mathrm{MIL}-101(\mathrm{Al})$ and $\mathrm{NH}_{2}-\mathrm{MIL}-53(\mathrm{Al})$ ) by immobilization. They concluded that POMs electrostatically interact with the MOF surface to form a stable composite. The thermal stability of the composites $\mathrm{PW}_{12} @ \mathrm{NH}_{2}-\mathrm{MIL}-53(\mathrm{Al})$ and $\mathrm{PW}_{12} @ \mathrm{NH}_{2}-\mathrm{MIL}-101(\mathrm{Al})$ was similar to the stability of the parent MOFs [37].

Besides MIL-101, Cu-BTC (namely HKUST-1 or MOF-199) has also been used as a host material to encapsulate Keggin- and Dawson-type POMs [38,39]. As shown in Table 1, the larger cages of Cu-BTC have an inner diameter of $1.3 \mathrm{~nm}$ and a pore window of $0.9 \mathrm{~nm}$, which perfectly ensures the stable entrapment of POMs. For example, $\mathrm{PW}_{12}$ with a diameter of approximately $1.06 \mathrm{~nm}$ was used as a structure directing agent for the self-assembly of Cu-BTC at room temperature [38]. The authors observed an enhanced chemical and thermal stability after the embedding of POM and no POM leaching was noted during catalysis in several studies [40,41]. In one of these studies, Shuxia Liu's group prepared a series of Keggin-type POMs in Cu-BTC, denoted as NENU-n, $\mathrm{n}=1 \sim 10$, and formulated as $\left[\mathrm{Cu}_{2}(\mathrm{BTC})_{4 / 3}\left(\mathrm{H}_{2} \mathrm{O}\right)_{2}\right]_{6}$ $\left[\mathrm{H}_{n} \mathrm{XM}_{12} \mathrm{O}_{40}\right] \cdot\left(\mathrm{C}_{4} \mathrm{H}_{12} \mathrm{~N}\right)_{2}(\mathrm{X}=\mathrm{Si}, \mathrm{Ge}, \mathrm{P}, \mathrm{As}, \mathrm{V}, \mathrm{Ti} ; \mathrm{M}=\mathrm{W}, \mathrm{Mo})$, by using a one-pot hydrothermal synthesis $[42,43]$. The templating effect of the POMs resulted in highly crystalline composite materials which showed an enhanced thermal stability. Moreover, as large crystals were obtained, the structures were elucidated by means of single-crystal X-ray diffraction, demonstrating that the Keggin polyanions were confined in the larger cuboctahedral cages (inner diameter of $1.3 \mathrm{~nm}$ ) [43].

Besides MIL-101 and Cu-BTC, isostructural imidazolate frameworks, namely ZIF-8 and ZIF-67, have also been frequently used as the host matrix. The sodalite-type cavities of ZIF- 8 have a size of approximately $1.1 \mathrm{~nm}$, but the accessible window of the cavity is rather small $(0.34 \mathrm{~nm})$. Keggin-based POMs possess a relatively larger particle size up to $1.3 \sim 1.4 \mathrm{~nm}$ in comparison to the cavities of ZIF-8, but can fit perfectly in their anionic form (1 nm diameter of $\left.\mathrm{PW}_{12}\right)$ [33]. Therefore, the bottle-around-the-ship method is an ideal approach for confining POMs inside ZIF-8 or ZIF-67 [44]. For instance, Malka et al. reported a POM encapsulated in ZIF-8 for its use as an esterification catalyst. The authors were able to obtain a $\mathrm{PW}_{12}$ loading of $18 \mathrm{wt} \%$ by using a one-pot synthesis strategy at room temperature in aqueous solution. However, after three catalytic cycles, degradation of the MOF occurred and $9 \%$ of the POM leached out [45]. A way to overcome the POM leaching in ZIF-8 was demonstrated in the work of Jeon et al. In this study, an impregnation method was used to functionalize the surface of the ZIF-8 nanoparticles with a Keggin-type $\mathrm{PW}_{12}$, in order to obtain a core-shell MOF-POM composite. Interestingly, due to the strong interaction, the POM-decorated MOF became insoluble in hydrophilic solvents [46].

Lin and co-workers constructed a POM@MOF molecular catalytic system with a Ni-containing POM $\left[\mathrm{Ni}_{4}\left(\mathrm{H}_{2} \mathrm{O}\right)_{2}\left(\mathrm{PW}_{9} \mathrm{O}_{34}\right)_{2}\right]^{10-}$ (namely $\left.\mathrm{Ni}_{4} \mathrm{P}_{2}\right)$ into an $\left[\operatorname{Ir}(\mathrm{ppy})_{2}(\text { bpy })\right]^{+}$-derived MOF by one-pot synthesis, and the MOF was isostructural to UiO-66, with extended ligands. $\mathrm{Ni}_{4} \mathrm{P}_{2}$ POMs can be encapsulated in the octahedral cages with an inner dimension of $2.2 \mathrm{~nm}$ [47].

In the studies mentioned above, the one-pot synthesis and wet impregnation methodology both give a high chance of success in the synthesis of POM-encapsulated MOFs. Although the impregnation method is straightforward, it is only applicable for MOF pore windows larger than the POMs. However, leaching of the POMs might happen unless precautions are taken in advance to ensure a good interaction 
between POM and MOF supports. The use of POMs as a template might enhance the crystallinity of the MOF framework, which makes a one-pot synthesis very attractive. However, it is important to note here that the size of the POM needs to be larger than the pore window of the MOFs to prevent leaching. In addition to this, the one-pot synthesis method is not applicable to all MOF structures. In most cases, the POM@MOFs materials obtained through a one-pot synthesis or impregnation method have a positive influence on the thermal stability in comparison to the parent non-functionalized MOF.

Besides the commonly used one-pot and impregnation method, there are some other efficient methods for constructing POM-encapsulated MOFs. In 2018, Zhong et al. synthesized NENU-3 (PW $12 @$ HKUST-1) by a liquid-assisted grinding method [48]. By using a two-step synthesis, PW $_{12}$ and the $\mathrm{Cu}$ salt were first dissolved and evaporated to obtain the copper salt of $\mathrm{PW}_{12}$. Hereafter, the $\mathrm{H}_{3} \mathrm{BTC}$ ligand was added in the presence of a small amount of alcohol ( $\mathrm{MeOH}$ and $\left.\mathrm{EtOH}\right)$, which was used as the grinding liquid. The mixture was ground for $5 \mathrm{~min}$ and the color gradually changed to blue. After washing and drying at $60{ }^{\circ} \mathrm{C}$ for $24 \mathrm{~h}$, the obtained nanocrystalline, NENU-3, showed a high crystallinity, and the surface area was slightly higher compared to NENU-3 obtained in one-pot solvothermal synthesis. In 2019, G. Li et al. employed an in-situ hot-pressing approach to encapsulate the Keggin-type $\mathrm{PW}_{12}$ into an indium-based MOF (MFM-300(In)) [49]. As shown in Figure 1, all the ingredients, including the POMs, were ground in the absence of a solvent, after which they were packed with an aluminum foil and heated on a plate at $80{ }^{\circ} \mathrm{C}$ for only 10 min to obtain PW 12 $_{12}$ MFM-300(In) composites. The resulting materials exhibited a high crystallinity and stability and no $\mathrm{PW}_{12}$ aggregates were observed on the MOF surface.

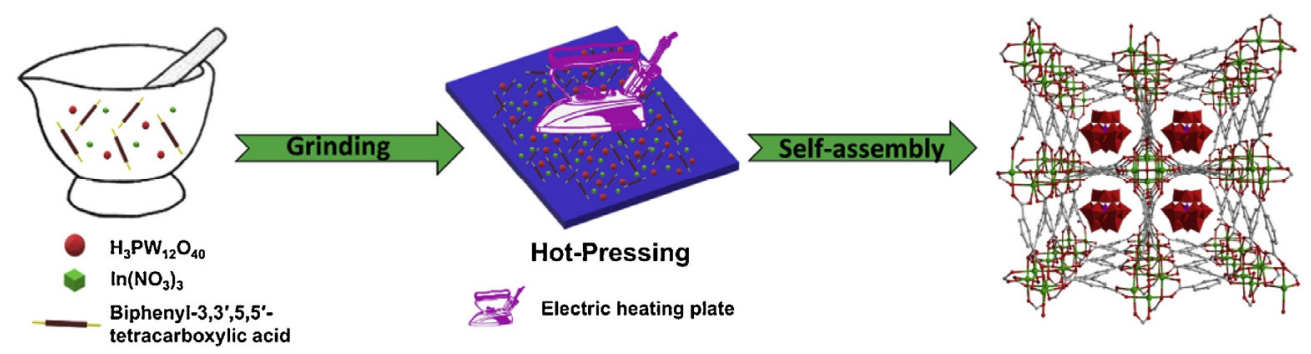

Figure 1. The hot-pressing synthesis process of $\mathrm{PW}_{12} @ M$ MF-300(In). Reprinted from [49]. Copyright (2019), with permission from Elsevier.

\section{Catalytic Applications}

\subsection{Organocatalysis}

\subsubsection{Oxidation Reaction}

Oxidation reactions are one of the most elementary reactions, and have already been extensively investigated by various catalytic systems. POM@MOF hybrid materials are considered as potential oxidation catalysts due to the presence of acidic sites within MOFs, along with the strong acidity and redox performance of POMs. Accordingly, some well-known MOFs have been reported to encapsulate POMs for their use in oxidation reactions, including $\mathrm{MIL}(\mathrm{Cr}, \mathrm{Fe}$, or $\mathrm{Al}), \mathrm{UiO}(\mathrm{Zr})$, and $\mathrm{ZIF}$ series, as well as Cu-BTC and NU-1000 frameworks. Among the different oxidation reactions, oxidative desulfurization (ODS) and the selective oxidation of alcohols and alkenes are the most studied reactions using POM@MOF catalysts.

ODS, as one of the promising methods for removing sulfur-containing compounds from fuels, has significant importance in both academic research and industrial chemistry. Since 2012, several Keggin- and sandwich-type POMs, including [A-PW $\left.\mathrm{PO}_{34}\right]^{9-}[50],\left[\mathrm{PW}_{12} \mathrm{O}_{40}\right]^{3-}[51-54],\left[\mathrm{PW}_{11} \mathrm{Zn}\left(\mathrm{H}_{2} \mathrm{O}\right) \mathrm{O}_{39}\right]^{5-}[55,56]$, $\left[\mathrm{Tb}\left(\mathrm{PW}_{11} \mathrm{O}_{39}\right)_{2}\right]^{11-}[57]$, and $\left[\mathrm{Eu}\left(\mathrm{PW}_{11} \mathrm{O}_{39}\right)_{2}\right]^{11-}[58]$, have been incorporated into the cavities of MIL(Cr, $\mathrm{Fe}$, or $\mathrm{Al}$ ) for the ODS reaction, using $\mathrm{H}_{2} \mathrm{O}_{2}$ as the oxidant. The heterogeneous POM@MIL catalysts could not only be easily recycled and reused, but also showed a higher catalytic activity compared to 
the homogeneous POM counterparts. For example, Balula's group reported that the heterogeneous $\mathrm{Tb}\left(\mathrm{PW}_{11}\right)_{2} @ \mathrm{MIL}-101\left(\mathrm{~Tb}\left(\mathrm{PW}_{11}\right)_{2}=\left[\mathrm{Tb}\left(\mathrm{PW}_{11} \mathrm{O}_{39}\right)_{2}\right]^{11-}\right)$ catalyst exhibits $95 \%$ conversion of benzothiophene (BT) at $50{ }^{\circ} \mathrm{C}$ after $2 \mathrm{~h}$, whereas the homogeneous $\mathrm{Tb}\left(\mathrm{PW}_{11}\right)_{2}$ catalyst affords a conversion of only $32 \%$ under the same reaction conditions [57]. Although the synthesized Tb(PW $\left.\mathrm{PW}_{11}\right)_{2} @ \mathrm{MIL}-101$ catalyst showed POM leaching, its structure and morphology remained intact after three consecutive ODS runs. Another study proved that the chemical and thermal stability of POM@MIL-101(Cr) systems could be enhanced compared to individual POMs and MOFs. More specifically, Silva's group demonstrated the high stability of the $\mathrm{PW}_{11} @ \mathrm{MIL}-101\left(\mathrm{PW}_{11}=\left[\mathrm{PW}_{11} \mathrm{O}_{39}\right]^{7-}\right)$ catalyst in aqueous $\mathrm{H}_{2} \mathrm{O}_{2}$, while $\mathrm{PW}_{11}$ decomposed into peroxo-complexes in the presence of $\mathrm{H}_{2} \mathrm{O}_{2}$ [59]. In addition, Naseri and co-workers observed that the thermal stability of the synthesized $\mathrm{P}_{2} \mathrm{~W}_{18} \mathrm{Ce}_{3} @ \mathrm{MIL}-101\left(\mathrm{P}_{2} \mathrm{~W}_{18} \mathrm{Ce}_{3}=\left[\left(\mathrm{OCe}^{\mathrm{IV}} \mathrm{O}\right)_{3}\left(\mathrm{PW}_{9} \mathrm{O}_{34}\right)_{2}\right]^{12-}\right)$ and $\mathrm{P}_{2} \mathrm{~W}_{18} \mathrm{Sn}_{3} @ \mathrm{MIL}-101\left(\mathrm{P}_{2} \mathrm{~W}_{18} \mathrm{Sn}_{3}=\left[\left(\mathrm{HOSn}{ }^{\mathrm{IV}} \mathrm{OH}\right)_{3}\left(\mathrm{PW}_{9} \mathrm{O}_{34}\right)_{2}\right]^{12-}\right)$ materials improved in comparison to the single MIL-101(Cr) framework. The thermally stable POM@MOF materials exhibited $>95 \%$ conversion of diphenyl sulfide after five cycles [29].

In an interesting study by Cao and co-workers, the effect of the window size within MOFs on the catalytic ODS performance of different POM@MOF materials was investigated [60]. In this work, $\mathrm{PW}_{12}$ was encapsulated into three robust MOFs with different window sizes, namely MIL-100(Fe) (8.6 and

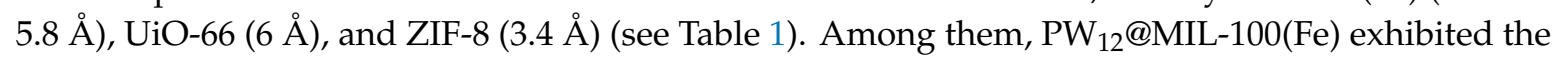
highest activity $(92.8 \%)$ for the oxidation of 4,6-dimethyldibenzothiophene $\left(3.62 \times 6.17 \times 7.86 \AA^{3}\right)$ compared to UiO-66 (39.1\%) and ZIF-8 (9.1\%). The observed higher activity was attributed to the large window size of MIL-100(Fe), which enabled a fast diffusion of the substrate into the cages. Another important parameter is the influence of the POM loading on the catalytic performance. The conversion of dibenzothiophene (DBT) was at least two times higher when 16\%-PW $12 @ \mathrm{MIL}-100(\mathrm{Fe})$ was used as a catalyst in comparison to the $7 \%-\mathrm{PW}_{12} @ \mathrm{MIL}-100(\mathrm{Fe})$ catalyst, owing to the higher POM loading. However, when the loading was increased to $35 \%$, the conversion of DBT decreased a lot due to partial pore blocking, which limited the diffusion of reactants to the active sites.

To further enhance the reactivity and recyclability of POM@MOF materials in ODS reactions, amine-functionalized MOFs were employed for encapsulating POMs owing to the strong electrostatic interaction between amine groups and $\mathrm{POM}$ anions, including $\mathrm{NH}_{2}-\mathrm{MIL}-101(\mathrm{Cr})$ [33], $\mathrm{NH}_{2}-\mathrm{MIL}-101$ (Al) [36,56], and $\mathrm{NH}_{2}-\mathrm{MIL}-53(\mathrm{Al})$ [58]. For instance, Cao and co-workers reported the incorporation of $\mathrm{PW}_{12}$ into $\mathrm{NH}_{2}-\mathrm{MIL}-101(\mathrm{Cr})$ as a catalyst for the ODS reaction. The obtained material gave a full conversion of DBT at $50{ }^{\circ} \mathrm{C}$ after $1 \mathrm{~h}$ [33]. Notably, the reusability tests indicated that the conversion of DBT remained unchanged during six consecutive catalytic cycles using $\mathrm{PW}_{12} @ \mathrm{NH}_{2}-\mathrm{MIL}-101(\mathrm{Cr})$ as a catalyst, due to the strong electrostatic interactions between $\mathrm{PW}_{12}$ and the amine groups. Another report by Su and co-workers showed that the $\mathrm{PW}_{12} @ \mathrm{MIL}-101(\mathrm{Cr})$-diatomite gave $98.6 \%$ conversion of DBT at $60^{\circ} \mathrm{C}$ for $2 \mathrm{~h}$ after three consecutive cycles, which was attributed to the high dispersion of POMs [54].

In addition to ODS reactions, the selective oxidation of alkenes [61-66] and alcohols [34] was evaluated using POM@MIL catalysts. For example, Bo and co-workers synthesized $\mathrm{H}_{3+\mathrm{x}} \mathrm{PMo}_{12-\mathrm{x}} \mathrm{V}_{\mathrm{x}} \mathrm{O}_{40} @ \mathrm{MIL}-100(\mathrm{Fe})(\mathrm{x}=0,1,2)$ materials and their catalytic performance were assessed in the oxidation of cyclohexene, using $\mathrm{H}_{2} \mathrm{O}_{2}$ as the oxidant [66]. Among them, the $\mathrm{H}_{4} \mathrm{PMo}_{11} \mathrm{VO}_{40} @ \mathrm{MIL}-100(\mathrm{Fe})$ material exhibited 83\% conversion of cyclohexene, with an excellent selectivity for 2-cyclohexene-1-one (90\%) after five successive catalytic cycles. In 2007, our group developed a new POM@MIL-101 catalyst based on dual amino-functionalized ionic liquid (DAIL) [34]. Firstly, DAIL was introduced onto the coordinatively unsaturated chromium sites of MIL-101(Cr) by a post-synthetic strategy, followed by immobilization of the Keggin-type $\mathrm{PW}_{12}$ onto the DAIL-modified MIL-101 through anion exchange (see Figure 2). The PW 12 /DAIL/MIL-101 catalyst exhibited a very high turnover number (TON: 1900) for the selective oxidation of benzyl alcohol towards benzaldehyde at $100{ }^{\circ} \mathrm{C}$ for $6 \mathrm{~h}$. The $\mathrm{PW}_{12} / \mathrm{DAIL} / \mathrm{MIL}-101$ catalyst demonstrated a higher catalytic activity compared to the PW 12 /MIL-101 catalyst without DAIL functionalities (TON: 1400 ). The higher activity was due to the presence of remaining free amino groups anchored on the imidazolium moieties of DAIL, which play a 
crucial role in enhancing the accessibility of TBHP as the oxidant. Moreover, the PW 12 /DAIL/MIL-101 catalyst was reused for at least five cycles, with no significant leaching of the tungsten species.

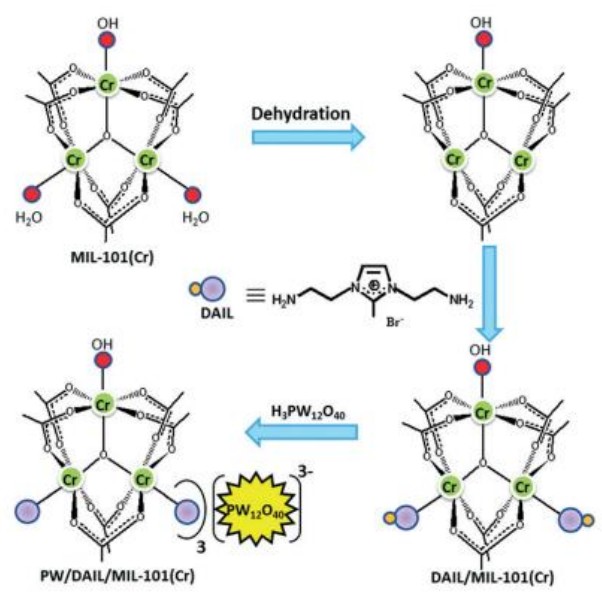

(a)

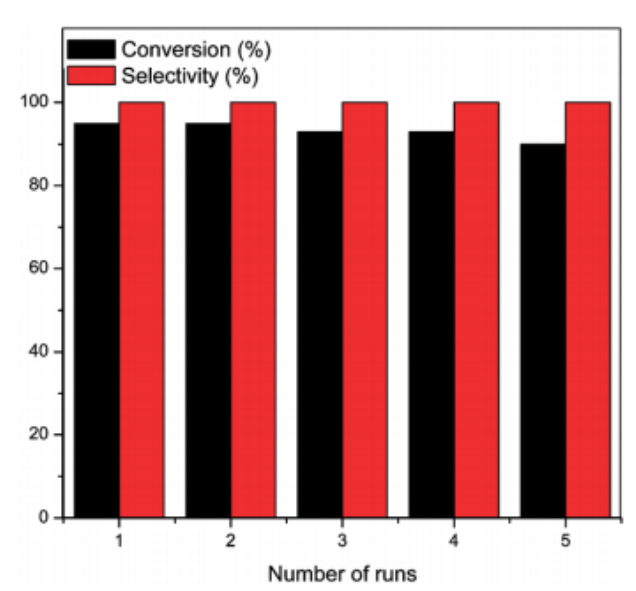

(b)

Figure 2. (a) Schematic illustration of the preparation of PW/dual amino-functionalized ionic liquid (DAIL)/MIL-101(Cr); (b) recyclability of the PW/DAIL/MIL-101(Cr) catalyst. Reprinted with permission from [34]. Copyright (2017), Royal Society of Chemistry.

Another type of MOF, namely Cu-BTC, has also been employed to encapsulate POMs. In 2008, six kind of Keggin-type POMs were encapsulated into Cu-BTC (named NENU-n, NENU = Northeast Normal University) using a one-pot hydrothermal method and their crystal structures were determined [43]. Subsequently, various POMs were encapsulated into the Cu-BTC framework and their catalytic performance was examined in ODS reactions $[67,68]$, the oxidation of alcohols $[69,70]$, olefins [39,71-73], benzene, and $\mathrm{H}_{2} \mathrm{~S}[41,74]$. For example, Zheng et al. prepared different sizes of nanocrystal-based catalysts, $\left[\mathrm{Cu}_{2}(\mathrm{BTC})_{4 / 3}\left(\mathrm{H}_{2} \mathrm{O}\right)_{2}\right]_{6}\left[\mathrm{H}_{5} \mathrm{PV}_{2} \mathrm{Mo}_{10} \mathrm{O}_{40}\right]$ (NENU-9N), by using various copper salts and adjusting the $\mathrm{pH}$ of the solution for the ODS reaction (see Figure 3) [75]. They proposed that the reaction kinetics can be facilitated by decreasing the size of the nanocrystals. The $550 \mathrm{~nm}$ NENU-9 showed a significantly higher conversion of DBT ( $90 \%)$ in 60 min compared to $300 \mu \mathrm{m}$ NENU-9 (41\%) and the homogeneous POM (2\%) in $90 \mathrm{~min}$. To further improve the stability of POM@MOF materials and their catalytic ODS performance, POM@MOF compounds were confined in other porous materials, e.g., MCM-41 [76,77], carbon nanotubes [78], mesoporous SBA-15 [79], and hollow ZSM-5 zeolite [80]. For example, POM@Cu-BTC was confined in the pores of MCM-41 to prevent deactivation of the catalyst [76]. The POM@Cu-BTC@MCM-41 (POM $\left.=\mathrm{Cs}_{2} \mathrm{HPMo}_{6} \mathrm{~W}_{6} \mathrm{O}_{40}\right)$ exhibited almost full conversion (99.6\%) of DBT in 180 min under optimal reaction conditions and could be reused more than 15 times without a significant loss of activity. Lu and co-workers prepared a series of POM@Cu-BTC $\left(\mathrm{POM}=\mathrm{PW}_{12},\left[\mathrm{PMo}_{12-\mathrm{x}} \mathrm{V}_{\mathrm{x}} \mathrm{O}_{40}\right]^{(3+\mathrm{x})-}(\mathrm{x}=0,1,2,3)\right)$ catalysts and investigated their performance for the oxidation of benzyl alcohol to benzaldehyde, with $\mathrm{H}_{2} \mathrm{O}_{2}$ as the oxidant (Figure 4) [70]. The authors observed that the vanadium-containing POMs improved the conversion of benzyl alcohol because of the high redox ability of the POMs. However, when increasing the vanadium content in the POMs, overoxidation to benzoic acid resulted in a lower selectivity towards benzaldehyde. The $\mathrm{PMo}_{12} @ \mathrm{Cu}$-BTC showed approximately 75\% conversion of benzyl alcohol with $\sim 90 \%$ selectivity towards benzaldehyde, whereas the $\mathrm{PMo}_{9} \mathrm{~V}_{3} @ \mathrm{Cu}-\mathrm{BTC}$ showed $\sim 98 \%$ conversion of benzyl alcohol with $\sim 65 \%$ selectivity using the same reaction conditions. In other words, the product distribution could be controlled by adjusting the redox capability of the POMs.

Interestingly, in a few studies, a synergistic effect between the POM and Cu-BTC was observed $[41,74,81]$. For example, Hill prepared CuPW $\mathrm{Cu}_{11} @ \mathrm{Cu}$-BTC $\left(\mathrm{CuPW}_{11}=\left[\mathrm{CuPW}_{11} \mathrm{O}_{39}\right]^{5-}\right)$ for the oxidation of several sulfur compounds and proposed synergistic effects between $\mathrm{PW}_{11} \mathrm{Cu}$ and 
Cu-BTC [41]. Not only the hydrolytic stability of the hybrid POM@MOF was improved, but also the TON (12), as the oxidation of $\mathrm{H}_{2} \mathrm{~S}$ under ambient conditions increased significantly compared to the individual Cu-BTC (0.02) and POM (no production).
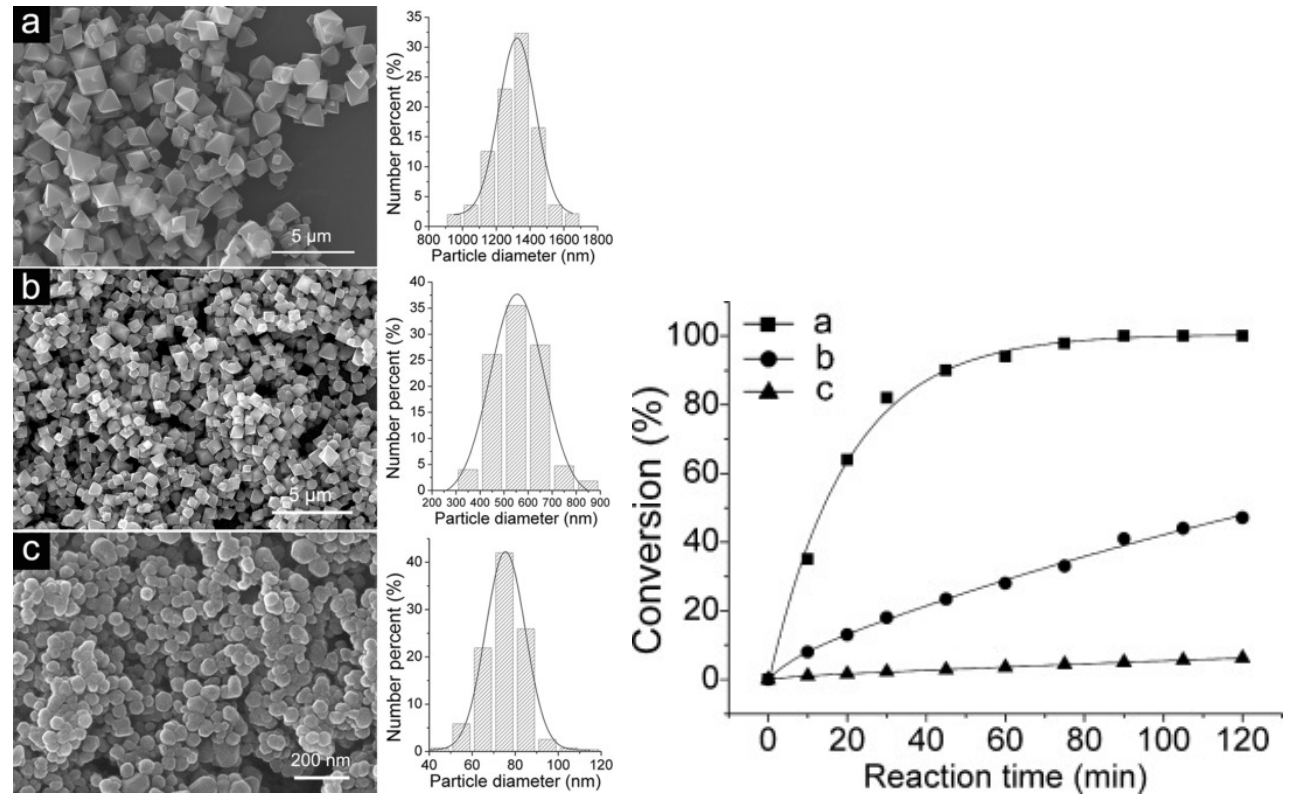

Figure 3. (a) Field emission SEM of Northeast Normal University (NENU)-9N with (a) copper nitrate as the metal source at $\mathrm{pH} 2.5$, (b) copper acetate as the metal source at $\mathrm{pH} 2.5$, and c) copper acetate as the metal source at $\mathrm{pH}$ 4.0. The percentage of DBT-to-DBTO ${ }_{2}$ conversion versus reaction time by using a) NENU-9N (average diameter $=550 \mathrm{~nm}$ ), (b) NENU-9 (average diameter $=300 \mathrm{~mm}$ ), and (c) POVM (average diameter $=300 \mathrm{~mm}$ ) as catalysts. Reaction conditions: catalyst $(0.01 \mathrm{mmol})$, DBT $(147 \mathrm{mg}, 0.8 \mathrm{mmol})$, and isobutyraldehyde $(0.72 \mathrm{~mL}, 8 \mathrm{mmol})$ in decalin $(50 \mathrm{~mL})$ at $80^{\circ} \mathrm{C}$. Reprinted with permission from [75]. Copyright (2013), John Wiley and Sons.

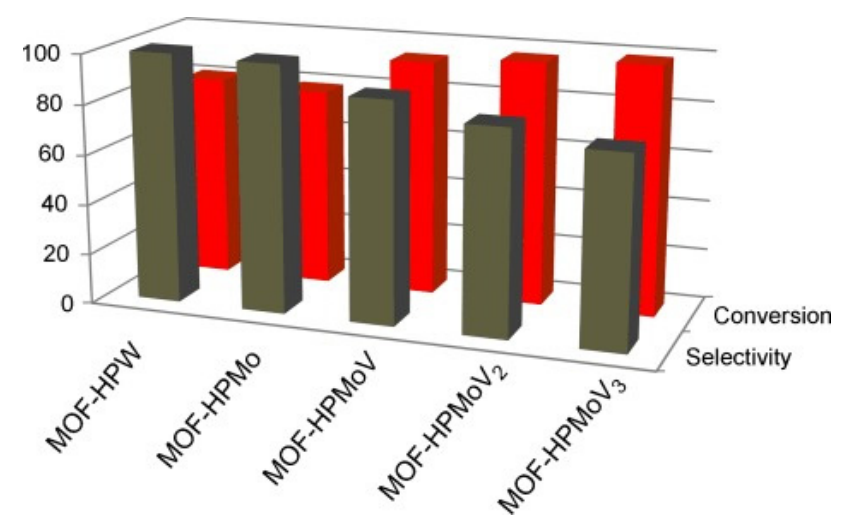

Figure 4. Oxidation of benzyl alcohol by different POM@MOF-199 catalysts. Reprinted with permission from [70]. Copyright (2014), John Wiley and Sons.

The robust Zr-based MOFs have also attracted much attention for hosting POMs for oxidation reactions. The earliest study on the introduction of POMs into a Zr-based MOF was reported by Dolbecq and co-workers in 2015 [82]. Three tungstate POMs ([PW $\left.{ }_{12} \mathrm{O}_{40}\right]^{3-}(12 \AA),\left[\mathrm{PW}_{11} \mathrm{O}_{39}\right]^{7-}$, and $\left.\left[\mathrm{P}_{2} \mathrm{~W}_{18} \mathrm{O}_{62}\right]^{6-}(14 \AA)\right)$ were encapsulated into the pores of UiO-67. Subsequently, Dai and co-workers examined the catalytic performance of 35\%-PW $\mathrm{PW}_{12} @ \mathrm{UiO}-66$ for the selective oxidation of cyclopentene (CPE) to glutaraldehyde (GA) [83]. The catalyst showed $~ 95 \%$ conversion of CPE, with a $\sim 78 \%$ yield for GA at $35{ }^{\circ} \mathrm{C}$ after $24 \mathrm{~h}$ of reaction. Unfortunately, the catalyst showed $\mathrm{PW}_{12}$ leaching $(\sim 3 \mathrm{wt} \%)$ after 
three catalytic cycles. To address this POM leaching issue, Yu and co-workers used UiO-bpy (bpy = 2,2'-bipyridine-5,5'-dicarboxylic acid) to encapsulate polyoxomolybdic cobalt (CoPMA) [84]. The bpy sites of the UiO-bpy framework provided an extra interaction with the POM compared to the UiO-67 without bpy moieties. The catalytic activities of CoPMA@UiO-bpy and CoPMA@UiO-67 were assessed in the oxidation of styrene, using $\mathrm{O}_{2}$ as the oxidant. The CoPMA@UiO-bpy exhibited the highest catalytic performance, with $80 \%$ conversion of styrene and $59 \%$ selectivity towards styrene epoxide.

Another Zr-based MOF, denoted as NU-1000, with small triangular (12 $⿱$ A) and larger hexagonal $(31 \AA)$ channels, has been used to support POMs such as $\left[\mathrm{PW}_{12} \mathrm{O}_{40}\right]^{3-}$ and $\left[\mathrm{PMo}_{10} \mathrm{~V}_{2} \mathrm{O}_{40}\right]^{5-}$ [85-87]. For example, Farha's group prepared $\mathrm{PW}_{12} @ \mathrm{NU}-1000$ through an impregnation method for the oxidation of 2-chloroethyl ethyl sulfide (CEES), using $\mathrm{H}_{2} \mathrm{O}_{2}$ as the oxidant. The authors demonstrated that the most likely location for $\mathrm{PW}_{12}$ clusters is in the small triangular channels, which was further confirmed by means of powder X-ray diffraction, scanning transmission electron microscopy, and difference envelope density analysis. At the same time, $\mathrm{PW}_{12} @ \mathrm{NU}-1000$ showed a higher conversion of CEES (98\% after $20 \mathrm{~min}$ ) compared to the pristine NU-1000 (77\% after $90 \mathrm{~min}$ ) and homogeneous POM (98\% after $90 \mathrm{~min}$ ). However, the $\mathrm{PW}_{12} @ \mathrm{NU}-1000$ exhibited only $57 \%$ selectivity towards 2-chloroethyl ethyl sulfoxide (CEESO). In a subsequent work, the authors demonstrated that the $\mathrm{PW}_{12}$ could migrate from the micropores to the mesopores of NU-1000 under mild thermal activation (see Figure 5). Moreover, the PW $12 @ N U-1000$ showed a full conversion of CEES after $5 \mathrm{~min}$, with 95\% selectivity towards CEESO. Recently, this group also prepared the $\mathrm{PV}_{2} \mathrm{Mo}_{10} @ \mathrm{NU}-1000$ catalyst by using the same method and the synthesized material showed a full conversion of CEES, with $\mathrm{O}_{2}$ as the oxidant.
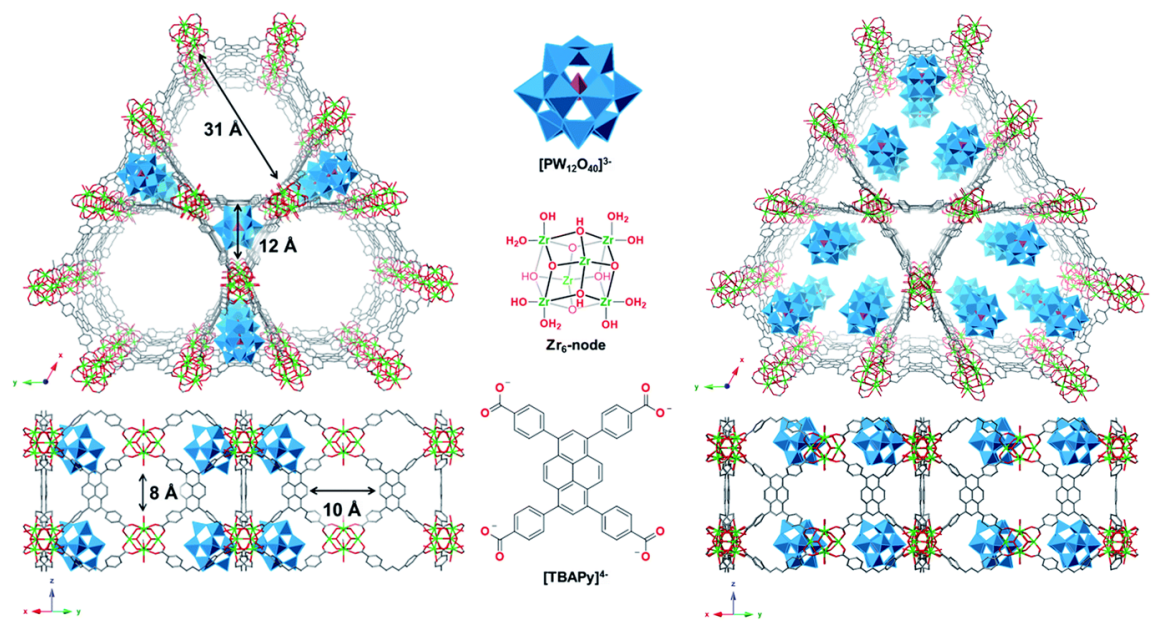

Figure 5. Structural representations of the $\mathrm{PW}_{12} @ \mathrm{NU}-1000$. Reprinted with permission from [86]. Copyright (2018), Royal Society of Chemistry.

In addition to the well-known MOFs, several other POM@MOF hybrid materials, including $\left[\mathrm{Co}(\mathrm{BBPTZ})_{3}\right]\left[\mathrm{HPMo}_{12} \mathrm{O}_{40}\right] \cdot 24 \mathrm{H}_{2} \mathrm{O}$ and $\left[\mathrm{Cu}_{6}{ }_{6}(\operatorname{trz})_{6}\left(\mathrm{PW}_{12} \mathrm{O}_{40}\right)_{2}\right]$, have been synthesized and applied for ODS [88], the oxidation of aryl alkenes [89,90], alkylbenzenes [91], and alcohols [92] (see Table 2).

Besides the use of POMs encapsulated in the cages of MOFs, some POMs have been covered on the surface of MOFs to achieve core-shell structured hybrid materials for oxidation reactions [46,93]. For example, $\mathrm{PW}_{12}$ was loaded onto the ZIF-8 surface to obtain a core-shell catalyst for the oxidation of benzyl alcohol. Notably, strong O-N bonding between $\mathrm{PW}_{12}$ and the imidazole group of the ZIF-8 was detected through $X$-ray photoelectron spectroscopy and X-ray absorption near-edge structure measurements. Accordingly, the ZIF-8@PW 12 material was insoluble in hydrophilic solvents. The ZIF-8@PW 12 material exhibited a high conversion of benzyl alcohol (>95\%), with $90 \%$ selectivity towards benzaldehyde, and outperformed the activity of pure $\mathrm{PW}_{12}(51 \%)$ and ZIF-8 (30\%). 
Table 2. Application of POM@MOF materials in heterogeneous catalysis.

\begin{tabular}{|c|c|c|c|c|c|}
\hline Entry & MOF & POM & $\begin{array}{l}\text { Synthesis } \\
\text { Approach }\end{array}$ & Catalytic Reaction & Ref. \\
\hline \multicolumn{6}{|c|}{ Organocatalysis } \\
\hline 1 & MIL-101(Cr) & $\mathrm{TBA}_{4.2} \mathrm{H}_{0.8}\left[\mathrm{PW}_{11} \mathrm{Zn}\left(\mathrm{H}_{2} \mathrm{O}\right) \mathrm{O}_{39}\right]$ & Impregnation & ODS & [55] \\
\hline 2 & MIL-101(Cr) & $\mathrm{H}_{3} \mathrm{PW}_{12} \mathrm{O}_{40}$ & One-pot & ODS & {$[52,54]$} \\
\hline 3 & MIL-101(Cr) & {$\left[\mathrm{Tb}\left(\mathrm{PW}_{11} \mathrm{O}_{39}\right)_{2}\right]^{11-}$} & Impregnation & ODS & [57] \\
\hline 4 & MIL-101(Cr) & $\mathrm{TBA}_{3} \mathrm{PW}_{12} \mathrm{O}_{40}$ & Impregnation & ODS & [51] \\
\hline 5 & $\begin{array}{l}\text { MIL-100(Fe) } \\
\text { UiO-66 } \\
\text { ZIF-8 }\end{array}$ & $\mathrm{H}_{3} \mathrm{PW}_{12} \mathrm{O}_{40}$ & One-pot & ODS & [60] \\
\hline 6 & $\begin{array}{c}\text { MIL-101(Cr) } \\
\mathrm{NH}_{2} \text {-MIL-53(Al) }\end{array}$ & {$\left[\mathrm{Eu}\left(\mathrm{PW}_{11} \mathrm{O}_{39}\right)_{2}\right]^{11-}$} & Impregnation & ODS & [58] \\
\hline 7 & $\mathrm{NH}_{2}$-MIL-101(Cr) & $\mathrm{H}_{3} \mathrm{PW}_{12} \mathrm{O}_{40}$ & Impregnation & ODS & [33] \\
\hline 8 & $\mathrm{NH}_{2}$-MIL-101(Al) & {$\left[\mathrm{PW}_{11} \mathrm{Zn}\left(\mathrm{H}_{2} \mathrm{O}\right) \mathrm{O}_{39}\right]^{5-}$} & $\begin{array}{l}\text { One-pot and } \\
\text { Impregnation }\end{array}$ & ODS & [56] \\
\hline 9 & MIL-100(Fe) & $\mathrm{H}_{3+\mathrm{x}} \mathrm{PMo}_{12-\mathrm{x}} \mathrm{V}_{\mathrm{x}} \mathrm{O}_{40}(\mathrm{x}=0,1,2)$ & One-pot & $\begin{array}{l}\text { Oxidation of } \\
\text { cyclohexene }\end{array}$ & [66] \\
\hline 10 & MIL-101(Cr) & $\mathrm{H}_{5} \mathrm{PV}_{2} \mathrm{Mo}_{10} \mathrm{O}_{40}$ & Impregnation & $\begin{array}{c}\text { Oxidation of } \\
\text { 2-chloroethyl ethyl } \\
\text { sulfide }\end{array}$ & [94] \\
\hline 11 & MIL-101(Cr) & $(\mathrm{TBA})_{7} \mathrm{H}_{3}\left[\mathrm{Co}_{4}\left(\mathrm{H}_{2} \mathrm{O}\right)_{2}\left(\mathrm{PW}_{9} \mathrm{O}_{34}\right)_{2}\right]$ & Impregnation & $\begin{array}{l}\text { Oxidation of alkenes and } \\
\text { cyclooctane }\end{array}$ & [65] \\
\hline 12 & MIL-101(Cr) & {$\left[\mathrm{PW}_{11} \mathrm{CoO}_{39}\right]^{5-}\left[\mathrm{PW}_{11} \mathrm{TiO}_{40}\right]^{5-}$} & Impregnation & Oxidation of alkenes & [62] \\
\hline 13 & MIL-101(Cr) & $\begin{array}{c}\left.\left(\mathrm{HOSn}^{\mathrm{IV}} \mathrm{OH}\right)_{3}\left(\mathrm{PW}_{9} \mathrm{O}_{34}\right)_{2}\right]^{12-} \\
{\left[\left(\mathrm{OCe}^{\mathrm{IV}} \mathrm{O}\right)_{3}\left(\mathrm{PW}_{9} \mathrm{O}_{34}\right)_{2}\right]^{12-}}\end{array}$ & Impregnation & $\begin{array}{l}\text { Selective oxidation of } \\
\text { various sulfides to } \\
\text { sulfones }\end{array}$ & [29] \\
\hline 14 & MIL-101(Cr) & $\begin{array}{l}{\left[\mathrm{PW}_{4} \mathrm{O}_{24}\right]^{3-}} \\
{\left[\mathrm{PW}_{12} \mathrm{O}_{40}\right]^{3-}}\end{array}$ & Impregnation & $\begin{array}{l}\text { Epoxidation of various } \\
\text { alkenes }\end{array}$ & [64] \\
\hline 15 & MIL-101(Cr) & $\mathrm{H}_{3} \mathrm{PW}_{12} \mathrm{O}_{40}$ & $\begin{array}{l}\text { One-pot and } \\
\text { Impregnation }\end{array}$ & $\begin{array}{l}\text { Selective oxidation of } \\
\text { sulfides to sulfoxides } \\
\text { and sulfones }\end{array}$ & [53] \\
\hline 16 & MIL-101(Cr) & {$\left[\mathrm{PZnMo}_{2} \mathrm{~W}_{9} \mathrm{O}_{39}\right]^{5-}$} & Impregnation & Oxidation of alkenes & [63] \\
\hline 17 & $\mathrm{NH}_{2}$-MIL-101(Al) & $\mathrm{H}_{3} \mathrm{PW}_{12} \mathrm{O}_{40}$ & One-pot & CO oxidation & [36] \\
\hline 18 & MIL-101(Cr) & $\mathrm{H}_{3} \mathrm{PMo}_{12} \mathrm{O}_{40}$ & One-pot & $\begin{array}{l}\text { Epoxidation of } \\
\text { propylene }\end{array}$ & [61] \\
\hline 19 & MIL-101(Cr) & $\mathrm{H}_{3} \mathrm{PW}_{12} \mathrm{O}_{40}$ & Impregnation & $\begin{array}{c}\text { Oxidation of various } \\
\text { alcohols }\end{array}$ & [34] \\
\hline 20 & MIL-101(Cr) & {$\left[\mathrm{A}-\mathrm{PW}_{9} \mathrm{O}_{34}\right]^{9-}$} & Impregnation & $\begin{array}{c}\text { ODS } \\
\text { Oxidation of geraniol } \\
\text { and R-(+)-limonene }\end{array}$ & [50] \\
\hline 21 & MIL-101(Cr) & $\begin{array}{l}{\left[\mathrm{PW}_{11} \mathrm{O}_{39}\right]^{7-}} \\
{\left[\mathrm{SiW}_{11} \mathrm{O}_{39}\right]^{8-}}\end{array}$ & Impregnation & Oxidation of alkenes & [59] \\
\hline 22 & Cu-BTC & $\mathrm{H}_{3+\mathrm{x}} \mathrm{PMo}_{12-\mathrm{x}} \mathrm{V}_{\mathrm{x}} \mathrm{O}_{40}(\mathrm{x}=1,2,3)$ & One-pot & $\begin{array}{l}\text { Synthesis of phenol from } \\
\text { benzene }\end{array}$ & [74] \\
\hline 23 & $\mathrm{Cu}-\mathrm{BTC}$ & $\mathrm{H}_{3} \mathrm{PW}_{12} \mathrm{O}_{40}$ & $\begin{array}{l}\text { Liquid-assisted } \\
\text { grinding method }\end{array}$ & $\begin{array}{l}\text { Degradation of } \\
\text { phenol }\end{array}$ & [48] \\
\hline 24 & Cu-BTC & $\begin{array}{c}\mathrm{H}_{6+\mathrm{n}} \mathrm{P}_{2} \mathrm{Mo}_{18-\mathrm{n}} \mathrm{V}_{\mathrm{n}} \mathrm{O}_{62} \cdot \mathrm{mH}_{2} \mathrm{O} \\
(\mathrm{n}=1-5)\end{array}$ & One-pot & ODS & [78] \\
\hline 25 & Cu-BTC & $\mathrm{Cs}^{+}$ion modified $\mathrm{H}_{3} \mathrm{PMo}_{6} \mathrm{~W}_{6} \mathrm{O}_{40}$ & One-pot & ODS & [77] \\
\hline 26 & Cu-BTC & $\begin{array}{c}\mathrm{H}_{3+\mathrm{x}} \mathrm{PMo}_{12-\mathrm{x}} \mathrm{V}_{\mathrm{x}} \mathrm{O}_{40}(\mathrm{x}=0,1,2,3) \\
\mathrm{H}_{3} \mathrm{PW}_{12} \mathrm{O}_{40}\end{array}$ & One-pot & $\begin{array}{l}\text { Selective oxidation of } \\
\text { alcohols }\end{array}$ & [70] \\
\hline 27 & Cu-BTC & $\begin{array}{c}\mathrm{H}_{3} \mathrm{PW}_{12} \mathrm{O}_{40} \\
\mathrm{H}_{3} \mathrm{PMo}_{12} \mathrm{O}_{40} \\
\mathrm{H}_{7}\left[\mathrm{P}\left(\mathrm{W}_{2} \mathrm{O}_{7}\right)\left(\mathrm{Mo}_{2} \mathrm{O}_{7}\right)_{6}\right] \\
\mathrm{H}_{4} \mathrm{SiW}_{12} \mathrm{O}_{40}\end{array}$ & One-pot & ODS & {$[67,68,80]$} \\
\hline 28 & Cu-BTC & $\mathrm{H}_{3} \mathrm{PW}_{12} \mathrm{O}_{40}$ & One-pot & $\begin{array}{l}\text { Oxidation of } \\
\text { cyclopentene to } \\
\text { glutaraldehyde }\end{array}$ & [72] \\
\hline 29 & $\mathrm{Cu}-\mathrm{BTC}$ & {$\left[\mathrm{CuPW}_{11} \mathrm{O}_{39}\right]^{5-}$} & One-pot & $\begin{array}{c}\text { Oxidation of thiols and } \\
\qquad \mathrm{H}_{2} \mathrm{~S}\end{array}$ & [41] \\
\hline 30 & Cu-BTC & $\mathrm{H}_{5} \mathrm{PMo}_{10} \mathrm{~V}_{2} \mathrm{O}_{40}$ & One-pot & ODS & [75] \\
\hline 31 & $\mathrm{Cu}-\mathrm{BTC}$ & $\mathrm{H}_{6} \mathrm{PMo}_{9} \mathrm{~V}_{3} \mathrm{O}_{40}$ & One-pot & $\begin{array}{l}\text { Oxidation of benzene to } \\
\text { phenol }\end{array}$ & [79] \\
\hline 32 & Cu-BTC & $\mathrm{H}_{3} \mathrm{PMo}_{6} \mathrm{~W}_{6} \mathrm{O}_{40}$ & One-pot & ODS & [76] \\
\hline 33 & $\mathrm{UiO}-66$ & $\mathrm{H}_{3} \mathrm{PW}_{12} \mathrm{O}_{40}$ & One-pot & $\begin{array}{l}\text { Selective oxidation of } \\
\text { cyclopentene to } \\
\text { glutaraldehyde }\end{array}$ & [83] \\
\hline
\end{tabular}


Table 2. Cont.

\begin{tabular}{|c|c|c|c|c|c|}
\hline Entry & MOF & POM & $\begin{array}{l}\text { Synthesis } \\
\text { Approach }\end{array}$ & Catalytic Reaction & Ref. \\
\hline 34 & $\begin{array}{l}\text { UiO-67 } \\
\text { UiO-bpy }\end{array}$ & $\mathrm{H}_{3} \mathrm{PMo}_{12} \mathrm{O}_{40}$ & One-pot & Olefins epoxidation & [84] \\
\hline 35 & NU-1000 & $\mathrm{H}_{5} \mathrm{PV}_{2} \mathrm{Mo}_{10} \mathrm{O}_{40} \mathrm{H}_{3} \mathrm{PW}_{12} \mathrm{O}_{40}$ & Impregnation & $\begin{array}{c}\text { Oxidation of } \\
\text { 2-chloroethyl ethyl } \\
\text { sulfide }\end{array}$ & [85-87] \\
\hline 36 & {$\left[\mathrm{Co}(\mathrm{BBPTZ})_{3}\right]\left[\mathrm{HP} \mathrm{Mo}{ }_{12} \mathrm{O}_{40}\right] \cdot 24 \mathrm{H}_{2} \mathrm{O}$} & $\mathrm{H}_{3} \mathrm{PMo}_{12} \mathrm{O}_{40}$ & One-pot & ODS & [88] \\
\hline 37 & $\begin{array}{c}{\left[\mathrm{Co}(\mathrm{BBTZ})_{2}\right]\left[\mathrm{H}_{3} \mathrm{BW}_{12} \mathrm{O}_{40}\right] \cdot 10 \mathrm{H}_{2} \mathrm{O}} \\
{\left[\mathrm{Co}_{3}\left(\mathrm{H}_{2} \mathrm{O}\right)_{6}(\mathrm{BBTZ})_{4}\right]\left[\mathrm{BW}_{12} \mathrm{O}_{40}\right] \cdot \mathrm{NO}_{3} \cdot 4 \mathrm{H}_{2} \mathrm{O}}\end{array}$ & {$\left[\mathrm{BW}_{12} \mathrm{O}_{40}\right]^{5-}$} & One-pot & $\begin{array}{l}\text { Oxidation of styrene to } \\
\text { benzaldehyde }\end{array}$ & [90] \\
\hline 38 & $\begin{array}{l}{\left[\mathrm{Cu}_{6}^{\mathrm{I}}(\mathrm{trz})_{6}\left(\mathrm{PW}_{12} \mathrm{O}_{40}\right)_{2}\right]} \\
{\left[\mathrm{Cu}_{3}{ }_{3}(\mathrm{trz})_{3}\left(\mathrm{PMo}_{12} \mathrm{O}_{40}\right)\right]}\end{array}$ & $\begin{array}{c}\mathrm{H}_{3} \mathrm{PMo}_{12} \mathrm{O}_{40} \\
\mathrm{H}_{3} \mathrm{PW}_{12} \mathrm{O}_{40}\end{array}$ & One-pot & $\begin{array}{l}\text { Oxidation of } \\
\text { alkylbenzenes to } \\
\text { aldehydes }\end{array}$ & [91] \\
\hline 39 & $\begin{array}{c}{\left[\mathrm{Cu}_{3}\left(4,4^{\prime} \text {-bpy }\right)_{3}\right]\left[\mathrm{HSiW}_{12} \mathrm{O}_{40}\right](\mathrm{imi})} \\
{\left[\mathrm{Cu}_{3}\left(4,4^{\prime}-\text { bpy }\right)_{3}\right]\left[\mathrm{PMo}_{12} \mathrm{O}_{40}\right](\mathrm{ampyd})} \\
{\left[\mathrm{Cu}_{2}\left(4,4^{\prime} \text {-bpy }\right)_{2}\right]\left[\mathrm{HPMo}_{12} \mathrm{O}_{40}\right](\mathrm{ampyd})} \\
{\left[\mathrm{Cu}(\mathrm{Phen})\left(4,4^{\prime}-\text { bpy }\right)\left(\mathrm{H}_{2} \mathrm{O}\right)\right]_{2}\left[\mathrm{PW}_{12} \mathrm{O}_{40}\right]\left(4,4^{\prime}-\text {-bpy }\right)}\end{array}$ & $\begin{array}{c}\mathrm{H}_{3} \mathrm{PW}_{12} \mathrm{O}_{40} \\
\mathrm{H}_{3} \mathrm{PMo}_{12} \mathrm{O}_{40} \\
\mathrm{H}_{4} \mathrm{SiW}_{12} \mathrm{O}_{40}\end{array}$ & One-pot & $\begin{array}{l}\text { Oxidation of various } \\
\text { alcohols }\end{array}$ & [69] \\
\hline 40 & $\begin{array}{c}\left.\mathrm{Ni}\left(4,4^{\prime}-\text { bpy }\right)_{2}\right]_{2}\left[\mathrm{~V}_{7}{ }^{\mathrm{IV}} \mathrm{V}_{9} \mathrm{~V}_{\left.\mathrm{O}_{38} \mathrm{Cl}\right]}\left(4,4^{\prime} \text {-bpy }\right)\right. \\
6 \mathrm{H}_{2} \mathrm{O}\end{array}$ & {$\left[\mathrm{V}_{7}{ }^{\mathrm{IV}} \mathrm{V}_{9} \mathrm{~V}_{\mathrm{O}_{38}} \mathrm{Cl}\right]^{4-}$} & One-pot & Oxidation of alkenes & [71] \\
\hline 41 & $\begin{array}{c}{\left[\mathrm{H}(\mathrm{bpy}) \mathrm{Cu}_{2}\right]\left[\mathrm{PW}_{12} \mathrm{O}_{40}\right]} \\
{\left[\mathrm{H}(\mathrm{bpy}) \mathrm{Cu}_{2}\right]\left[\mathrm{PMo}_{12} \mathrm{O}_{40}\right]}\end{array}$ & $\begin{array}{c}\mathrm{H}_{3} \mathrm{PMo}_{12} \mathrm{O}_{40} \\
\mathrm{H}_{3} \mathrm{PW}_{12} \mathrm{O}_{40}\end{array}$ & One-pot & $\begin{array}{l}\text { Oxidation of } \\
\text { ethylbenzene, alcohol, } \\
\text { and cyclooctene }\end{array}$ & [89] \\
\hline 42 & $\mathrm{H}\left[\mathrm{Cu}_{5}{ }_{5} \mathrm{Cu}^{\mathrm{II}}(\mathrm{pzc})_{2}(\mathrm{pz})_{4.5}\left(\mathrm{P}_{2} \mathrm{~W}_{18} \mathrm{O}_{62}\right)\right] \cdot 6 \mathrm{H}_{2} \mathrm{O}$ & {$\left[\mathrm{P}_{2} \mathrm{~W}_{18} \mathrm{O}_{62}\right]^{6-}$} & One-pot & Oxidation of alcohols & [92] \\
\hline 43 & {$\left[\mathrm{Cu}^{\mathrm{I}}(\mathrm{bbi})\right]_{2}\left(\left[\mathrm{Cu}^{\mathrm{I}}(\mathrm{bbi})\right]_{2} \mathrm{~V}^{\mathrm{IV}}{ }_{2} \mathrm{~V}_{8}{ }_{8} \mathrm{O}_{26}\right) \cdot 2 \mathrm{H}_{2} \mathrm{O}$} & {$\left[\mathrm{V}_{10} \mathrm{O}_{26}\right]^{4-}$} & One-pot & $\begin{array}{c}\text { Oxidative cleavage of } \\
\beta-\mathrm{O}-4 \text { lignin }\end{array}$ & [81] \\
\hline 44 & ZIF-8 & $\mathrm{Mo}_{132}$ & Impregnation & ODS & [93] \\
\hline 45 & ZIF-8 & $\mathrm{H}_{3} \mathrm{PW}_{12} \mathrm{O}_{40}$ & Impregnation & $\begin{array}{l}\text { Oxidation of benzyl } \\
\text { alcohol }\end{array}$ & [46] \\
\hline \multicolumn{6}{|c|}{ Condensation reaction } \\
\hline 46 & ZIF-8 & $\begin{array}{l}\mathrm{Al}_{0.66}-\mathrm{DTP} \\
\text { Horic }\end{array}$ & One-pot & $\begin{array}{c}\text { Aldol condensation of } \\
\text { 5-hydroxymethylfurfural } \\
\text { (HMF) with acetone }\end{array}$ & [95] \\
\hline 47 & MIL-101(Cr) & $\mathrm{H}_{3} \mathrm{PW}_{12} \mathrm{O}_{40}$ & Impregnation & $\begin{array}{l}\text { Biginelli condensation } \\
\text { reaction }\end{array}$ & [96] \\
\hline 48 & MIL-101(Cr) & $\mathrm{H}_{3} \mathrm{PW}_{12} \mathrm{O}_{40}$ & One-pot & $\begin{array}{l}\text { Cyclopentanone } \\
\text { self-condensation }\end{array}$ & [97] \\
\hline 49 & MIL-101(Cr) & $\mathrm{H}_{3} \mathrm{PW}_{12} \mathrm{O}_{40}$ & $\begin{array}{l}\text { One-pot and } \\
\text { Impregnation }\end{array}$ & Baeyer condensation & {$[98,99]$} \\
\hline 50 & MIL-101(Cr) & $\mathrm{H}_{3} \mathrm{PW}_{12} \mathrm{O}_{40}$ & $\begin{array}{l}\text { One-pot and } \\
\text { Impregnation }\end{array}$ & $\begin{array}{l}\text { Knoevenagel } \\
\text { condensation of } \\
\text { benzaldehyde with ethyl } \\
\text { cyanoacetate }\end{array}$ & [30] \\
\hline 51 & $\begin{array}{l}\mathrm{NH}_{2}-\mathrm{MIL}-101(\mathrm{Al}) \\
\mathrm{NH}_{2}-\mathrm{MIL}-53(\mathrm{Al})\end{array}$ & $\mathrm{H}_{3} \mathrm{PW}_{12} \mathrm{O}_{40}$ & $\begin{array}{c}\text { Impregnation } \\
\text { and Joint Heating }\end{array}$ & $\begin{array}{c}\text { Aldehyde condensation } \\
\text { and polymerization }\end{array}$ & [37] \\
\hline 52 & $\begin{array}{l}\text { MIL-100(Fe) } \\
\text { MIL-101(Cr) }\end{array}$ & $\mathrm{H}_{3} \mathrm{PW}_{12} \mathrm{O}_{40}$ & One-pot & $\begin{array}{l}\text { Hydroxyalkylation of } \\
\text { phenol with } \\
\text { formaldehyde }\end{array}$ & [100] \\
\hline \multicolumn{6}{|c|}{ Esterification reaction } \\
\hline 53 & $\begin{array}{l}\text { MIL-100(Fe) } \\
\text { Cu-BTC }\end{array}$ & $\mathrm{H}_{3} \mathrm{PW}_{12} \mathrm{O}_{40}$ & One-pot & $\begin{array}{l}\text { Enzymatic esterification } \\
\text { of cinnamic acid }\end{array}$ & [101] \\
\hline 54 & $\mathrm{Cu}-\mathrm{BTC}$ & $\mathrm{H}_{3} \mathrm{PW}_{12} \mathrm{O}_{40}$ & One-pot & $\begin{array}{l}\text { Esterification of acetic } \\
\text { acid with 1-propanol }\end{array}$ & [102] \\
\hline 55 & $\mathrm{Cu}-\mathrm{BTC}$ & $\mathrm{H}_{3} \mathrm{PMo}_{12} \mathrm{O}_{40}$ & One-pot & $\begin{array}{l}\text { Esterification of levulinic } \\
\text { acid (LA) and ethanol }\end{array}$ & [103] \\
\hline 56 & $\mathrm{UiO}-66$ & $\mathrm{H}_{4} \mathrm{SiW}_{12} \mathrm{O}_{40}$ & One-pot & $\begin{array}{l}\text { Esterification of lauric } \\
\text { acid with methanol }\end{array}$ & [104] \\
\hline 57 & MIL-101(Cr) & $\mathrm{K}_{5}\left[\mathrm{CoW}_{12} \mathrm{O}_{40}\right]$ & One-pot & $\begin{array}{l}\text { Esterification of acetic } \\
\text { acid with various } \\
\text { alcohols, and } \\
\text { cycloaddition of } \mathrm{CO}_{2} \\
\text { with epoxides }\end{array}$ & [105] \\
\hline 58 & $\mathrm{Cu}-\mathrm{BTC}$ & $\begin{array}{c}\mathrm{H}_{3} \mathrm{PW}_{12} \mathrm{O}_{40} \\
\mathrm{H}_{3} \mathrm{PMo}_{12} \mathrm{O}_{40}, \mathrm{H}_{4} \mathrm{PVMo}_{11} \mathrm{O}_{40} \\
\mathrm{H}_{5} \mathrm{PV}_{2} \mathrm{Mo}_{10} \mathrm{O}_{40}, \mathrm{H}_{6} \mathrm{PV}_{3} \mathrm{Mo}_{9} \mathrm{O}_{40}\end{array}$ & One-pot & $\begin{array}{c}\text { Oxidative esterification } \\
\text { of } \\
\text { glycerol }\end{array}$ & [106] \\
\hline 59 & ZIF-8 & $\mathrm{H}_{3} \mathrm{PW}_{12} \mathrm{O}_{40}$ & One-pot & $\begin{array}{l}\text { Esterification of benzoic } \\
\text { anhydride with } \\
\text { cinnamyl alcohol }\end{array}$ & [45] \\
\hline 60 & Fe-BTC & $\mathrm{H}_{3} \mathrm{PMo}_{12} \mathrm{O}_{40}$ & One-pot & $\begin{array}{l}\text { Esterification of free } \\
\text { fatty acids to biodiesel }\end{array}$ & [107] \\
\hline
\end{tabular}


Table 2. Cont

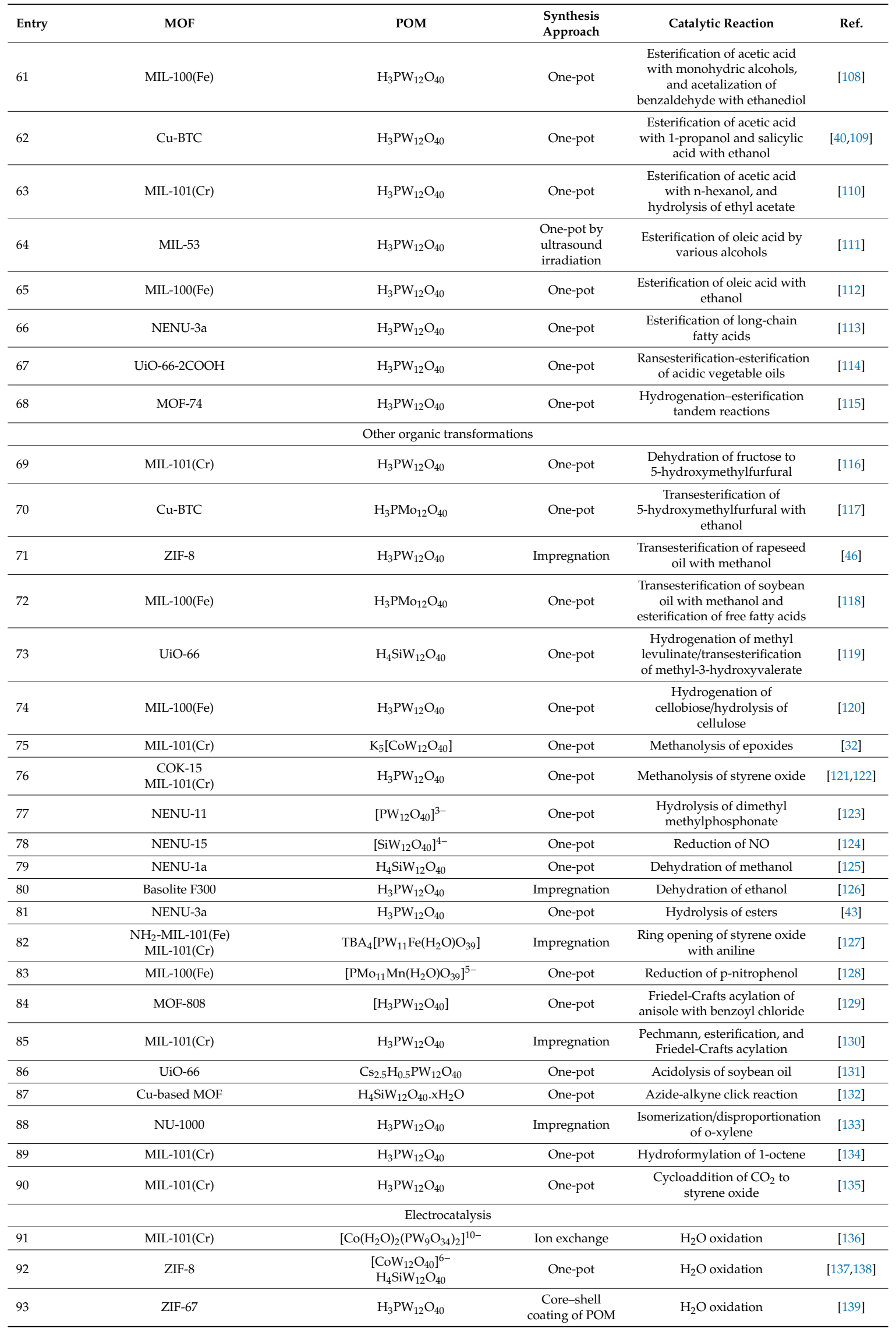


Table 2. Cont.

\begin{tabular}{|c|c|c|c|c|c|}
\hline Entry & MOF & РОМ & $\begin{array}{l}\text { Synthesis } \\
\text { Approach }\end{array}$ & Catalytic Reaction & Ref. \\
\hline 94 & Ag-based metal-organic nanotubes & $\begin{array}{l}\mathrm{H}_{3} \mathrm{PW}_{12} \mathrm{O}_{40} \\
\mathrm{H}_{4} \mathrm{SiW}_{12} \mathrm{O}_{40} \\
\end{array}$ & One-pot & $\mathrm{H}_{2}$ evolution & [140] \\
\hline 95 & Cu-based metal-organic nanotubes & $\begin{array}{c}\mathrm{K}_{6} \mathrm{P}_{2} \mathrm{~W}_{18} \mathrm{O}_{62} \\
\mathrm{H}_{6} \mathrm{As}_{2} \mathrm{~W}_{18} \mathrm{O}_{62}\end{array}$ & One-pot & $\mathrm{H}_{2}$ evolution & [141] \\
\hline 96 & MIL-101(Cr) & {$\left[\mathrm{PMo}_{10} \mathrm{~V}_{2} \mathrm{O}_{40}\right]^{5-}$} & Impregnation & Oxidation of ascorbic acid & [142] \\
\hline \multicolumn{6}{|c|}{ Photocatalysis } \\
\hline 97 & $\mathrm{NH}_{2}$-MIL-101(Al) & $\mathrm{K}_{6}\left[\mathrm{a}-\mathrm{AgPW}_{11} \mathrm{O}_{39}\right]$ & Impregnation & Degradation of Rhodamine B & [143] \\
\hline 98 & Cu-based MOF & $\mathrm{H}_{4} \mathrm{SiMo}_{12} \mathrm{O}_{40}$ & One-pot & Degradation of Rhodamine B & [144] \\
\hline 99 & MFM-300(In) & $\mathrm{H}_{3} \mathrm{PW}_{12} \mathrm{O}_{40}$ & $\begin{array}{c}\text { In situ } \\
\text { hot-pressing }\end{array}$ & $\begin{array}{l}\text { Degradation of } \\
\text { sulfamethazine }\end{array}$ & [49] \\
\hline 100 & MOF-545 & {$\left[\left(\mathrm{PW}_{9} \mathrm{O}_{34}\right)_{2} \mathrm{Co}_{4}\left(\mathrm{H}_{2} \mathrm{O}\right)_{2}\right]^{10-}$} & Impregnation & Water oxidation & $\begin{array}{l}{[145,} \\
146]\end{array}$ \\
\hline 101 & MIL-100(Fe) & $\begin{array}{l}{\left[\mathrm{Co}^{\mathrm{II}} \mathrm{Co}^{\mathrm{III}} \mathrm{W}_{11} \mathrm{O}_{39}\left(\mathrm{H}_{2} \mathrm{O}\right)\right]^{7-}} \\
{\left[\mathrm{Co}_{4}\left(\mathrm{PW}_{9} \mathrm{O}_{34}\right)_{2}\left(\mathrm{H}_{2} \mathrm{O}\right)_{2}\right]^{10-}} \\
\end{array}$ & One-pot & Water oxidation & [147] \\
\hline 102 & MIL-100(Fe) & $\mathrm{H}_{3} \mathrm{PMo}_{12} \mathrm{O}_{40}$ & One-pot & $\begin{array}{l}\text { Oxidation of alcohols and } \\
\text { reduction of } \mathrm{Cr}(\mathrm{VI})\end{array}$ & [148] \\
\hline 103 & Zn-based MOF & {$\left[\mathrm{BW}_{12} \mathrm{O}_{40}\right]^{5-}$} & One-pot & $\begin{array}{l}\text { Coupling of amines and } \\
\text { epoxidation of olefins }\end{array}$ & [149] \\
\hline 104 & $\mathrm{UiO}-66-\mathrm{NH}_{2}$ & $\mathrm{H}_{3} \mathrm{PW}_{12} \mathrm{O}_{40}$ & One-pot & $\begin{array}{c}\mathrm{H}_{2} \text { evolution/degradation of } \\
\text { Rhodamine B }\end{array}$ & [150] \\
\hline 105 & $\mathrm{NH}_{2}$-MIL-53 & $\mathrm{H}_{3} \mathrm{PW}_{12} \mathrm{O}_{40}$ & Impregnation & $\mathrm{H}_{2}$ evolution & {$[151]$} \\
\hline 106 & $\mathrm{UiO}-67$ & {$\left[\mathrm{P}_{2} \mathrm{~W}_{18} \mathrm{O}_{62}\right]^{6-} \mathrm{H}_{4} \mathrm{SiW}_{12} \mathrm{O}_{40}$} & One-pot & $\mathrm{H}_{2}$ evolution & $\begin{array}{l}{[152,} \\
153]\end{array}$ \\
\hline 107 & UiO derived structure & {$\left[\mathrm{Ni}_{4}\left(\mathrm{H}_{2} \mathrm{O}\right)_{2}\left(\mathrm{PW}_{9} \mathrm{O}_{34}\right)_{2}\right]^{10-}$} & One-pot & $\mathrm{H}_{2}$ evolution & [47] \\
\hline 108 & MIL-101(Cr) & $\begin{array}{c}\alpha-\mathrm{PW}_{15} \mathrm{~V}_{3}, \alpha-\mathrm{P}_{2} \mathrm{~W}_{17} \mathrm{Ni} \\
\alpha-\mathrm{P}_{2} \mathrm{~W}_{17} \mathrm{Co}\end{array}$ & One-pot & $\mathrm{H}_{2}$ evolution & [154] \\
\hline 109 & SMOF-1 & {$\left[\mathrm{P}_{2} \mathrm{~W}_{18} \mathrm{O}_{62}\right]^{6-}$} & Impregnation & $\mathrm{H}_{2}$ evolution & [155] \\
\hline 110 & Cu-BTC & {$\left[\mathrm{PTi}_{2} \mathrm{~W}_{10} \mathrm{O}_{4}\right]^{7-}$} & One-pot & $\mathrm{CO}_{2}$ reduction & [42] \\
\hline
\end{tabular}

BBPTZ = 4,4'-bis(1,2,4-triazol-1-ylmethyl)biphenyl]; BBTZ = 1,4-bis(1,2,4-triazol-1-ylmethyl)benzene; trz = 1,2,4-triazole; imi = imidazole; ampyd = 2-aminopyridine; bpy = bipyridine; Phen = 1,10-phenanthroline; bipy = 4,4'-bipyridine; Hpzc = pyrazine-2-carboxylic acid, $\mathrm{pz}=$ pyrazine; bbi =1,1'-(1,4-butanediyl)bis(imidazole); DTP = dodecatungstophosp; TBA = tetrabutylammonium.

\subsubsection{Condensation Reaction}

POM@MOF has revealed potential applications in a range of condensation reactions for producing value-added cyclic organic compounds. Recently, Malkar et al. compared the catalytic performance of three different catalysts, namely 20\%-Cs-DTP-K10, 18\%-DTP@ZIF-8, and $\mathrm{Al}_{0.66}$-DTP@ZIF-8 (DTP = dodecatungstophosp), for the aldol condensation of HMF (5-hydroxymethylfurfural), as shown in Figure 6 [95]. It has been proved that the substitution of protons of heteropolyacids with metal ions increases the mobility of protons, which results in an enhancement of the acidity. Based on $\mathrm{NH}_{3}$-TPD analysis, Cs-DTP-K10 displays the highest acidity $\left(1.51 \mathrm{mmol} \mathrm{g}^{-1}\right)$, whereas DTP@ZIF-8 and Al-DTP@ZIF-8 possess 0.44 and $0.54 \mathrm{mmol} \mathrm{g}^{-1}$ of acidic sites, respectively. Cs-DTP-K10, with the highest acidity, showed the highest activity for the aldol condensation of HMF and acetone to selectively produce the desired C9 product ( $71.6 \%$ after $6 \mathrm{~h}$ of reaction), while the selectivity was only $43.1 \%$. Although the total number of acidic sites was much lower in the case of the Al-DTP@ZIF-8 catalyst, a good conversion of $63.1 \%$ was still obtained after $6 \mathrm{~h}$ of reaction, which is comparable to the former value. Notably, the Al-DTP@ZIF-8 catalyst displayed a much higher selectivity ( 92\%) towards the C9 product compared to $\mathrm{C} 15$. The lowest conversion of HMF was achieved in the case of the 18\%-DTP@ZIF-8 material with the lowest acidity. However, a high selectivity towards the C9 product was observed. The higher selectivity towards the C9 adduct, as the desired product in the presence of the DTP@ZIF-8 and Al-DTP@ZIF-8 catalysts, confirms the shape selectivity supplied by the small pore diameter of ZIF-8, which can prevent the production of the C15 adduct. 


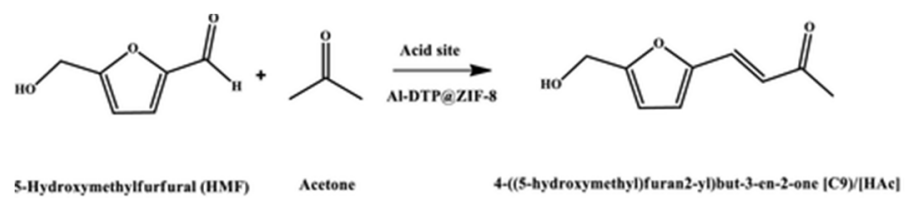

5-Hydroxymethylfurfural (HMF) Acetone
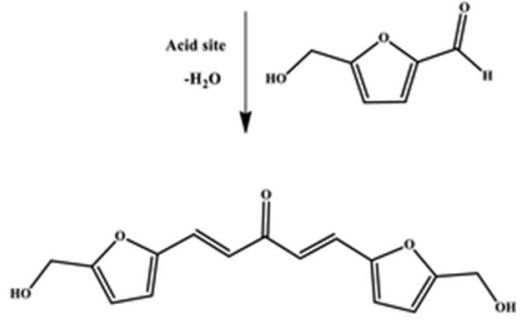

1,5 bis[5-hydroxymethyl-2-furany] $\mid-1,4$ pentandien-3-one $[\mathrm{C} 15]|\mathrm{HAcH}|$

Figure 6. Aldol condensation of 5-hydroxymethylfurfural (HMF) with acetone over Al-DTP@ZIF-8. Reproduced with permission from [95]. Copyright (2019), American Chemical Society.

Another example of the use of MOFs in condensation reactions is the well-known MIL-101. For this purpose, $\mathrm{PW}_{12} @$ MIL-101(Cr) composites were synthesized through the direct hydrothermal procedure or post-synthesis modification route [98]. The acidic sites within the MIL-101 and PW12@MIL-101(Cr) materials are desirable for catalyzing the Baeyer condensation of benzaldehyde and 2-naphthol, in the three-component condensation of benzaldehyde, 2-naphthol, and acetamide, as depicted in Figure 7. While no product was produced in the absence of catalysts, a high yield of around $95 \%$ was observed for the formation of 1-amidoalkyl-2-naphthol at $130{ }^{\circ} \mathrm{C}$ using microwave heating for $5 \mathrm{~min}$. Moreover, no leaching of the active sites was observed, and the catalyst could be reused for four cycles without a notable loss in the product yield.

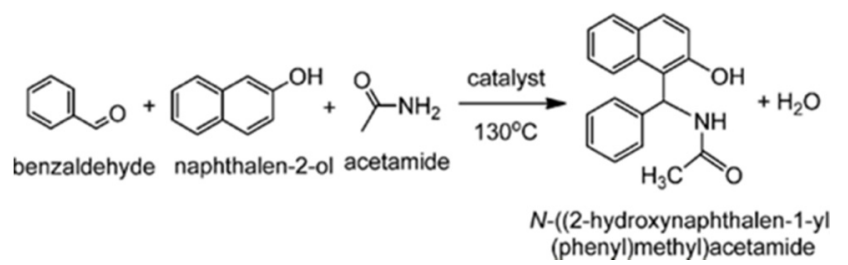

Figure 7. Condensation of benzaldehyde, 2-Naphthol, and acetamide. Reprinted with permission from [98]. Copyright (2012), American Chemical Society.

In addition, $\mathrm{PW}_{12}$ clusters were uniformly encapsulated in the cages of MIL-101 as a selective heterogeneous catalyst for the self-condensation of cyclic ketones [97]. As can be observed in Figure 8, the self-condensation of cyclopentanone can result in three different products based on the active sites in the applied catalysts. By using $\mathrm{PW}_{12}$ as the catalyst, a conversion of around $78 \%$ could be obtained after $24 \mathrm{~h}$ reaction to trindane as the main product. However, $\mathrm{PW}_{12} @ \mathrm{MIL}-101$ exhibits a considerably higher selectivity ( $>98 \%$ ) towards the mono-condensed component (2-cyclopentylidenecyclopentanone) as

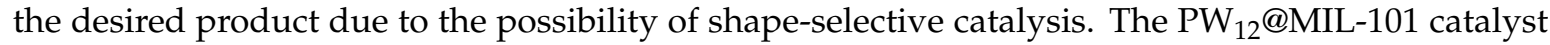
could be recycled up to five cycles, with no obvious reduction in the conversion and selectivity. 


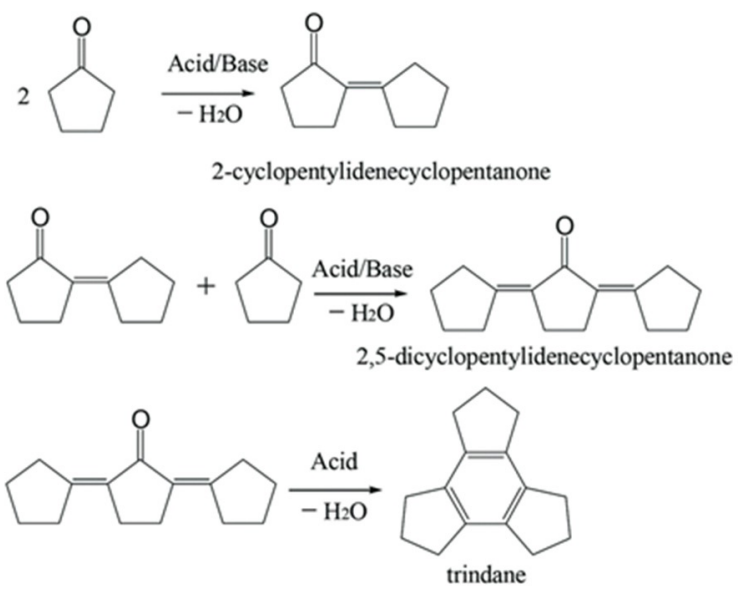

Figure 8. Reaction figure of a cyclopentanone self-condensation reaction. Adapted with permission from [97]. Copyright (2015), Royal Society of Chemistry.

\subsubsection{Esterification Reaction}

Modified MOFs with POMs can be employed as active catalysts for a wide range of esterification reactions. Biodiesel, as a secure and sustainable energy source, is a promising alternative for fossil fuel-based energy systems [156]. Among the various methods for biodiesel production, transesterification is the most common procedure. Recently, Xie et al. investigated the catalytic one-pot transesterification-esterification of acidic vegetable oil transesterification reaction over a functionalized UiO-66-2COOH with a Keggin-type POM, namely, AILs/POM/UiO-66-2COOH (AIL = sulfonated acidic ionic liquid) (see Figure 9) [114]. The prepared catalyst displayed synergistic benefits arising from the introduction of AIL as Brønsted acid sites. The presence of both Brønsted acid sites of ILs and Lewis acid sites of POM promoted the catalytic reaction for green biodiesel production. The control experiments showed that all of the applied POMs ( $\mathrm{PW}_{12}, \mathrm{SiW}_{12}$, and $\mathrm{PMo}_{12}$ ) could convert soybean oil to biodiesel with a high catalytic performance (conversion of $\sim 100 \%$ ). However, challenges associated with the work-up and recyclability of these homogeneous catalysts limit their potential application. The pristine UiO-66-2COOH material presented a poor activity, with an oil conversion of around $8 \%$ because of its insufficient acidic properties. In addition, the $\mathrm{PW}_{12} @ \mathrm{UiO}-66-2 \mathrm{COOH}$, $\mathrm{SiW}_{12} @ \mathrm{UiO}-66-2 \mathrm{COOH}$, and $\mathrm{PMo}_{12} @ \mathrm{UiO}-66-2 \mathrm{COOH}$ composites suffered from sluggish reaction kinetics with conversions below $30 \%$ towards biodiesel production, which could have been due to the lack of enough acidic sites required to advance the catalytic reaction. Another control experiment was performed by using the sulfonic acid-functionalized IL as the homogeneous catalyst, affording a high catalytic activity of around $99 \%$ conversion. It is interesting to note that AILs/POM/UiO-66-2COOH catalysts can combine the advantages of POMs, AILs, and porous MOFs and therefore present the highest catalytic performance in the mentioned reaction (conversion $>90 \%$ ). Furthermore, the strong interaction between the POMs and AILs was able to hinder the leaching of active components into the reaction media, which further resulted in no notable loss in the catalytic conversion of oil to biodiesel after five consecutive catalytic cycles. 


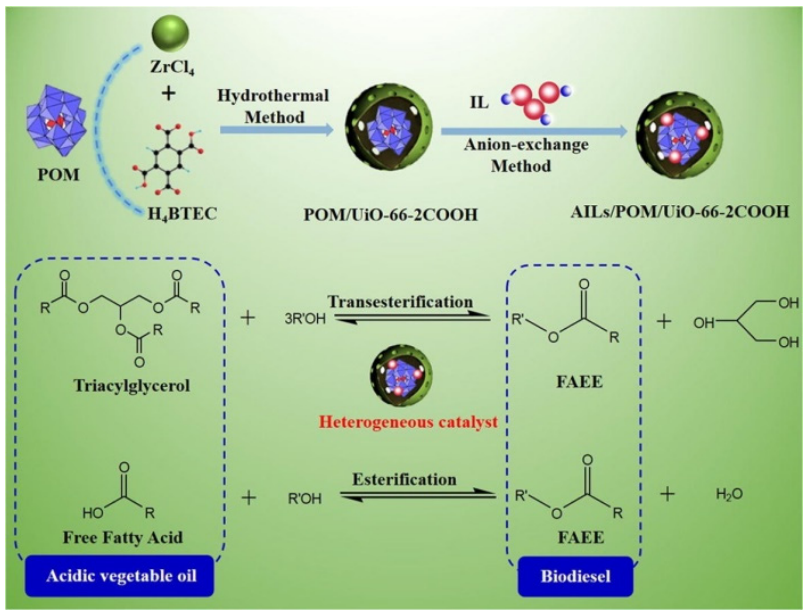

Figure 9. Synthesis procedure of the AILs/HPW/UiO-66-2COOH catalyst, and one-pot transesterificationesterification of acidic vegetable oils. Reprinted from [114]. Copyright (2019), with permission from Elsevier.

In 2015, Liu et al. described an effective procedure for designing NENU-3a with different crystal morphologies (cubic and octahedral) comprised of a Cu-BTC skeleton and encapsulated phosphotungstic acid catalyst [113]. The morphology of this framework was generated by applying the method of coordination modulation, using P-toluic acid as the modulator. The NENU-3a with cubic crystals ((100) facets) could effectively promote the conversion of long-chain (C12-C22) fatty acids into corresponding monoalkyl esters ( $>90 \%$ yield) compared to the octahedral counterpart $(<22 \%$ yield). Moreover, the cubic NENU-3a catalyst was highly robust and could be reused for five reaction runs with a preserved structure and catalytic activity. This report confirms the vital impact of morphological control on MOFs for improving the facet exposure of catalytic sites, which accordingly results in an enhancement of the catalytic performance, especially for bulky substrates with limited access to the catalytic active sites within the pores of MOF catalysts. Another important feature of MOFs is the possibility to control the product selectivity arising from the pore size effect of MOFs. Within this context, Zhu et al. studied the selective esterification of glycerol using a MOF-supported POM catalyst [106]. The catalytic performance of the obtained POM@Cu-BTC catalyst was compared to the metal oxide-supported POMs as the reference materials. Since there was no pore limitation impact using the POM@metal-oxide catalyst, the conversion of glycerol stopped at the acid stage without further reaction and was free to be released from the reaction site (Figure 10). However, when the POM@Cu-BTC catalyst was applied, diffusion of the acid product within the MOF pores was limited and further reaction of the acid product produced the corresponding ester compound.

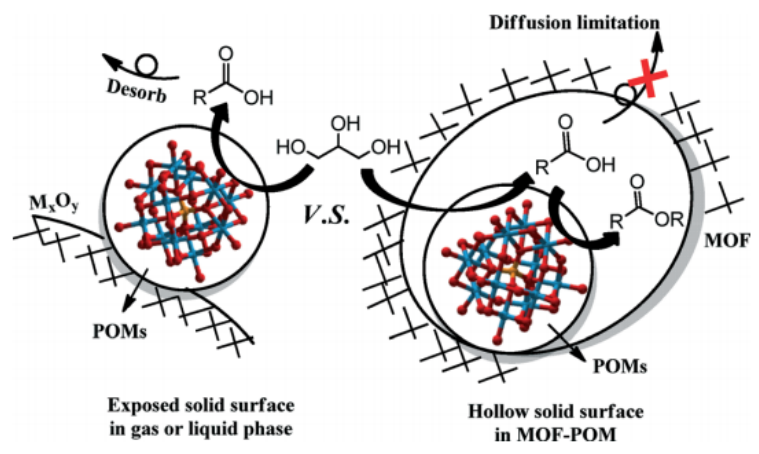

Figure 10. Diffusion limited glycerol transformation on MOF-POMs. Reprinted with permission from [106]. Copyright (2015), Royal Society of Chemistry. 


\subsubsection{Other Organic Transformations}

POMs exhibit great potential as solid acid catalysts because of their strong Brønsted acidity. The first report on a well-defined MOF-supported POM compound, which behaved as a true heterogeneous acid catalyst, was reported by Su et al. [43]. In this work, a series of POM@MOF catalysts were synthesized using a one-pot method. The POM@MOF compound, which contained the strongest Keggin Brønsted acid $\mathrm{PW}_{12}$, was examined in the hydrolysis of ethyl acetate in the presence of an excess amount of water. This catalyst, denoted as NENU-3a, exhibited almost full conversion $(>95 \%)$ after approximately $7 \mathrm{~h}$ of reaction, which is far more superior than most inorganic solid acids and comparable to organic solid acids. More specifically, when the activity was reported per unit of acid, NENU-3a was 3-7 times more active than $\mathrm{H}_{2} \mathrm{SO}_{4}, \mathrm{PW}_{12}$, nafion- $\mathrm{H}$, and Amberlyst-15. In addition to this, no deactivation of the acid sites by water was observed and no leaching of the POM was noted up to at least 15 cycles. Later on, the same group reported the use of POMs as templates for the construction of novel hybrid compounds, for which the properties of the POM could be tailored towards a specific application [123-125]. One of these targeted applications was the adsorption and subsequent hydrolysis of the nerve gas dimethyl methylphosphate to methyl alcohol, for which the conversion increased up to $93 \%$ when the temperature was raised to $50^{\circ} \mathrm{C}$ [123]. Recycling tests demonstrated that the structural integrity was preserved up until at least 10 cycles. However, it is important to note here that a stabilizing effect of the POM on the MOF will only be obtained when the shape, size, and symmetry of the POM match the MOF host [135]. This stabilizing effect even allowed the application of POM@MOF catalysts in aggressive reactions, as was demonstrated in the very nice work of Hupp, Farha, and Notestein [133]. In this study, the Zr-based MOF, NU-1000, was loaded with $\mathrm{H}_{3} \mathrm{PW}_{12} \mathrm{O}_{40}$ for its use in the strong acid-catalyzed reaction of o-xylene isomerization/disproportionation at $250{ }^{\circ} \mathrm{C}$ (see Figure 11). At low POM loadings (0.3 to $0.7 \mathrm{POM}$ per $\mathrm{Zr}_{6}$ node), no activity was observed, which was due to the collapse of the POM and/or MOF structure upon activation or at the start of the reaction. However, when the loading was increased to its maximum, with 1 Keggin unit per unit cell of NU-1000, the hybrid catalyst exhibited an initial reactivity in the examined C-C skeletal rearrangement reaction which was even higher than that of the reference $\mathrm{WO}_{\mathrm{x}}-\mathrm{ZrO}_{2}$ catalyst.

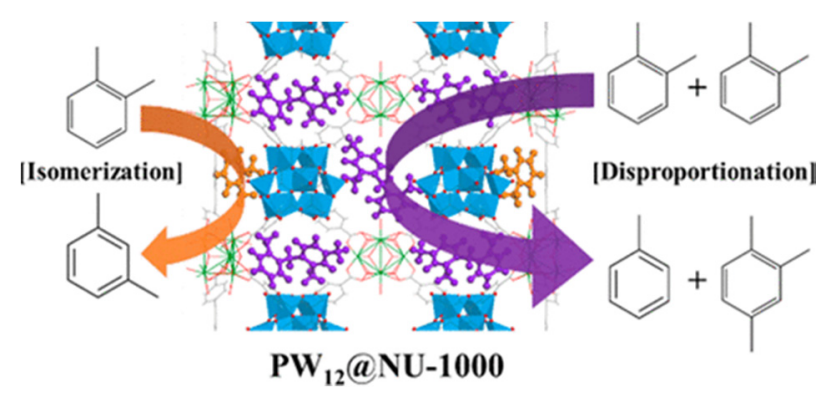

Figure 11. Phosphotungstic acid encapsulated in NU-1000 for its use in the aggressive hydrocarbon isomerization reaction. Reprinted with permission from [133]. Copyright (2018), American Chemistry Society.

While, in the previously discussed studies, the Keggin ion acted as a template to stabilize the microporous/mesoporous structure of the MOF, the group of Martens et al. used this templating mechanism to introduce mesopores separated by uniform microporous walls in a single crystal structure [121] (see Figure 12). More specifically, a hierarchical variant of the $\mathrm{Cu}$-based MOF, $\mathrm{Cu}-\mathrm{BTC}$, was synthesized using a dual templating approach in which the Keggin ions served as a molecular template for the structural motif of the MOF, while the surfactant cetyltrimethylammonium bromide was used to introduce mesoporosity. The resulting mesoporous MOF, denoted as COK-15, was investigated in the alcoholysis of styrene oxide, which often suffers from a low selectivity. The COK- 15 catalyst not only exhibited a remarkable activity (100\% conversion), but also achieved $100 \%$ selectivity for 2 methoxy- 2 phenylethanol after $3 \mathrm{~h}$ of reaction at $40{ }^{\circ} \mathrm{C}$. For comparison, the microporous POM@Cu-BTC and Cu-BTC material only showed $40 \%$ and 
$2 \%$ conversion, respectively. The authors addressed the good activity of the COK- 15 to the mesoporous feature, which allowed efficient mass transport. Moreover, the catalyst could be recycled for at least four runs, with a negligible loss in activity and selectivity.

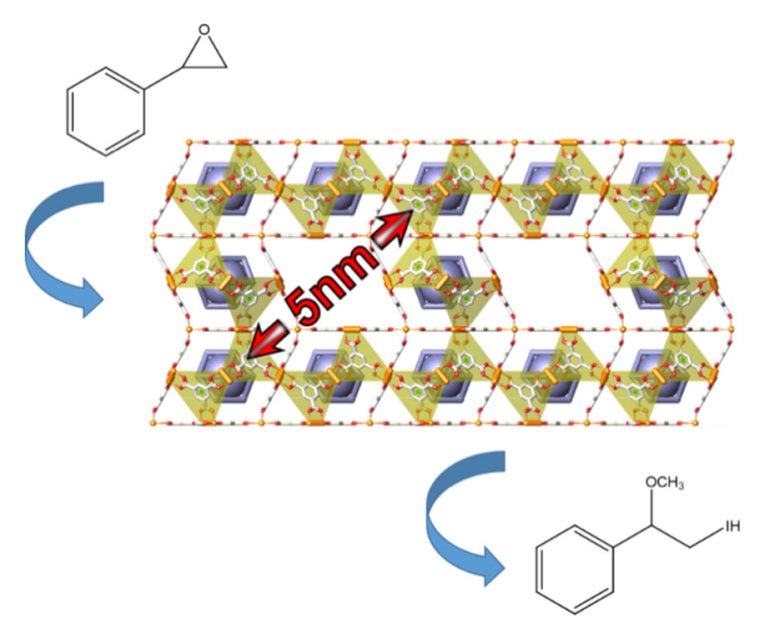

Figure 12. A copper benzene tricarboxylate metal-organic framework, COK-15, with a wide permanent mesoporous feature stabilized by Keggin POM ions for the methanolysis of styrene oxide. Adapted with permission from [121]. Copyright (2012), American Chemistry Society.

Besides this increase in stability after the embedding of the POM in a MOF support, several groups have demonstrated the mutual activation of the POM guest and MOF support $[32,119,127]$. A very special and extreme example of such a synergism was demonstrated in the work of Kögerler et al. [128]. In this work, a POM@MOF composite was prepared through a hydrothermal reaction in which an Mn-based POM was added to the reaction mixture to synthesize MIL-100. The obtained $30 \mathrm{wt} \%$ loaded Mn-POM@MIL-100 was evaluated for its catalytic performance in the reduction of p-nitrophenol to p-aminophenol in the presence of $\mathrm{NaBH}_{4}$. While both the individual compounds exhibited no catalytic activity, the composite showed an excellent performance (the activity and rate constant at $50{ }^{\circ} \mathrm{C}$ were $683 \mathrm{~L} \mathrm{~g}^{-1} \mathrm{~s}^{-1}$ and $0.23 \mathrm{~min}^{-1}$, respectively), which was even comparable to those observed for noble metal-based catalysts. The authors stated that the high catalytic activity originated from the fact that the Mn-POM facilitated the electron transfer from $\mathrm{BH}_{4}{ }^{-}$to the $\mathrm{Fe}^{3+}$ Lewis acid sites of the MOF, as they assumed that the MIL-100 alone could not accept electrons directly from $\mathrm{BH}_{4}^{-}$. Additionally, the group of Shul observed a distinct acid-base synergy upon examination of the core-shell structured heteropoly acid-functionalized ZIF-8 in the transesterification of rapeseed oil with methanol to produce biodiesel [46]. More than $95 \%$ of the rapeseed oil was converted to biodiesel due to the simultaneous presence of the acid functionalities of the POM and the basicity of the imidazolate groups of the MOF, whereas the pure POM and ZIF-8 catalysts showed a catalytic performance of $61 \%$ and $32 \%$, respectively. Moreover, the strong chemical O-N bonding between the Keggin and the imidazole units ensured a good recyclability, with no noticeable decrease in the catalytic performance after five cycles and no POM leaching.

\subsection{Electrocatalysis}

Besides the use of POM@MOF hybrids in organocatalysis, POMs also exhibit interesting electrocatalytic properties as they can undergo fast and reversible multi-electron transfers [157]. Within this context, POMs have already shown great potential in the electrochemical oxygen evolution reaction (OER) in a homogenous manner [158]. Despite the remarkable progress in this field, there are only a few reports on the encapsulation of POMs in the cages of MOFs for electrocatalytic water oxidation, as can be seen in Table 2. This is probably due to the fact that the majority of MOFs possess a low electrical conductivity and high hydrophobicity. The first report on the encapsulation of an unsubstituted Keggin POM in a MOF to perform electrocatalytic water oxidation was reported by 
Das et al. [137]. More specifically, a one-pot synthesis was performed to include the $\left[\mathrm{CoW}_{12} \mathrm{O}_{40}\right]^{6-}$ anion in the size matching cage of ZIF-8 (see Figure 13). During the electrochemical measurements, performed at $\mathrm{pH} 1.9$, the authors observed a clear shift to a less anodic potential for the redox $\mathrm{Co}$ III/Co $/ \mathrm{Co}^{\mathrm{II}}$ couple in the cyclic voltammogram of POM@MOF with respect to that of the uncapsulated POM (from $1.14 \mathrm{~V}$ for the Keggin POM to $0.97 \mathrm{~V}$ for the composite material). In addition to this, the POM@MOF catalyst exhibited an excellent stability as only a very small drop in the catalytic current was observed after 1000 catalytic cycles and no leaching of Co species was observed. It is, however, important to note here that, although the catalyst exhibited a high turnover frequency (TOF $=12.5 \mathrm{~s}^{-1}$ based on the quantitative oxygen evolution) and an excellent faradaic efficiency of $95.7 \%$, a rather high overpotential was required $\left(784.19 \mathrm{mV}\right.$ at a current density of $\left.1 \mathrm{~mA} \mathrm{~cm}^{-2}\right)$.

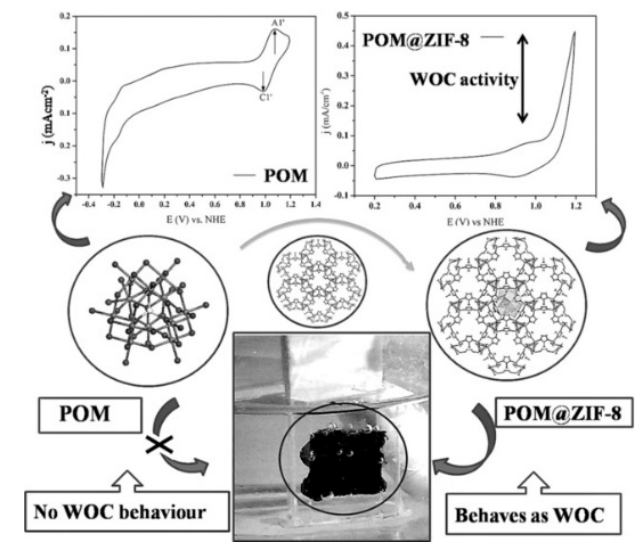

Figure 13. Encapsulation of an inactive Keggin POM in ZIF-8 to become an active oxygen evolution reaction (OER) catalyst. Reprinted with permission from [137]. Copyright (2018), John Wiley and Sons.

In a very recent report of the same group, a redox inactive $\mathrm{SiW}_{12} \mathrm{POM}$ was used to lower the required overpotential [138]. The co-encapsulation of this POM together with the true catalyst, an Fe(salen) complex, within ZIF-8 resulted in a decrease of the overpotential of more than $150 \mathrm{mV}$. In the absence of the encapsulated POM, the Fe-salen@ZIF-8 required an overpotential of $672.9 \mathrm{mV}$ to attain a current density of $1 \mathrm{~mA} \mathrm{~cm}^{-2}$, while in the presence of the POM, the overpotential decreased to $516 \mathrm{mV}$. The authors attributed this observation to the fact that the POM not only increased the hydrophilicity of the catalyst and facilitated the charge conduction in ZIF-8, but also ensured a higher loading of the Fe-salen complex within ZIF-8. Another way to decrease this overpotential for oxygen evolution and thus improve the hydrogen production efficiency was reported by Pang and co-workers [139]. In this work, the authors demonstrated the successful coating of ZIF-67 with a catalytically active Keggin POM, $\mathrm{H}_{3} \mathrm{PW}_{12} \mathrm{O}_{40}$. The unique yolk/shell structure of the ZIF-67@POM catalyst ensured a high electrical conductivity and fast charge transfer, which resulted in a significant reduction of the overpotential. From all of the examined ZIF-67@POM hybrids, the 6-ZIF-67@POM catalyst exhibited the smallest Tafel slope (58 $\mathrm{mV} \mathrm{dec}^{-1}$ ) and lowest overpotential values $\left(287,313\right.$, and $338 \mathrm{mV}$ at current densities of 10,20 , and $30 \mathrm{~mA} \mathrm{~cm}^{-2}$, respectively), which are even comparable to those observed for $\mathrm{RuO}_{2}$, which is one of the most efficient and well-known electrocatalysts for the OER reaction [159].

Besides these few examples on OER, POMs have also shown great potential in the second half reaction for water-splitting, namely the hydrogen evolution reaction (HER) [160]. However, to solve their shortcomings, particularly the limited stability of POMs in the required highly acidic $\mathrm{pH}$ for HER, Zhang et al. encapsulated POMs in metal-organic nanotubes (MONTs), which can be considered as a special kind of MOF $[140,141]$. Upon encapsulation of the POMs, using a one-pot synthesis method, the chemical stability of both the POM and MONTs increased. The POMs served as a kind of template to construct the MONTs, while the MONTs ensured a sort of a shield to increase the chemical stability of the POM. The best POM@MONTs electrocatalyst displayed an overpotential of $131 \mathrm{mV}$ (at a current 
density of $10 \mathrm{~mA} \mathrm{~cm}^{-2}$ ), which is far more superior than other POM-based MOFs (which showed overpotentials above $200 \mathrm{mV}$ ) [161].

\subsection{Photocatalysis}

Given the extraordinarily large-scale utilization of solar energy, POM@MOF materials have become particularly attractive for their use in visible-light-driven photocatalytic reactions. In particular, their use as catalysts for proton reduction has received considerable attention in recent years. Within this context, Lin's group reported on the integration of the two required components, namely the photosensitizer $\left[\mathrm{Ru}(\mathrm{bpy})_{3}\right]^{2+}$ or $\left[\operatorname{Ir}(\mathrm{ppy})_{2}(\mathrm{bpy})\right]^{+}$and hydrogen evolution catalyst, into $\mathrm{Zr}$-based MOFs to perform proton reduction $[47,152]$. For example, by using a one-pot self-assembly synthesis strategy, a transition metal Ni-based anionic POM was embedded into the highly cationic MOF by using a pre-functionalized $\left[\operatorname{Ir}(\text { ppy })_{2}(\mathrm{bpy})\right]^{+}$-derived dicarboxylate ligand [47]. In contrast to the homogeneous mixture of POM and the Ir-functionalized ligand, which only produced trace amounts of $\mathrm{H}_{2}(\mathrm{TON}=2)$, a TON of 1476 was observed for the hierarchically-organized POM@MOF assembly, which allowed facile electron transfer due to the proximity of the $\mathrm{Ni}_{4} \mathrm{P}_{2}$ to multiple photosensitizers in $\mathrm{Ni}_{4} \mathrm{P}_{2} @ M O F$. Another simple strategy for accommodating antenna molecules into MOFs was demonstrated in the work of Wang et al., in which several transition metal-substituted (V, Ni, and Co) Wells-Dawson-type POM@MIL-101(Cr) were prepared using one-pot synthesis [154]. Prior to the photocatalytic evaluation, the cationic photosensitizer $\left[\mathrm{Ru}(\mathrm{bpy})_{3}\right]^{2+}$ was adsorbed onto the POM@MOF, for which they observed that the adsorption ability was significantly enhanced upon increasing the POM loading. The photocatalytic performance of the three POM@MOF frameworks was significantly higher in comparison to their homogeneous counterpart and remained nearly unchanged after three additional cycles. Another very nice work in which $\left[\mathrm{Ru}(\mathrm{bpy})_{3}\right]^{2+}$ was also used as a photosensitizer was reported by Li et al. [155]. They reported the first water-soluble supramolecular MOF, denoted as SMOF-1, which was built by a self-assembly process from the hexaarmed $\left[\mathrm{Ru}(\mathrm{bpy})_{3}\right]^{2+}$-based precursor and cucurbit uril (CB) (see Figure 14). The resulting polycationic SMOF-1 exhibited only a weak gas adsorption ability, but was able to accommodate the bulky redox active $\left[\mathrm{P}_{2} \mathrm{~W}_{18} \mathrm{O}_{62}\right]^{6-}$ anion. The hydrogen production of the resulting WD-POM@SMOF-1 was about four times higher than that of its heterogeneous system. More specifically, in acidic media and using methanol as a sacrificial electron donor, the TON and $\mathrm{H}_{2}$ production rate was 392 and $3.553 \mu \mathrm{mol} \mathrm{g}^{-1} \mathrm{~h}^{-1}$, respectively. The authors attributed this high activity to the unique one-cage-one-guest encapsulation pattern, which allowed (i) a quick diffusion and close contact of the hydronium and methanol molecules and (ii) facile electron transfer from the excited $\left[\mathrm{Ru}(\mathrm{bpy})_{3}\right]^{2+}$ to the WD-POM. In addition to this, the catalyst could be recovered by evaporation of the solvent and could be reused at least six times without a significant decrease in TON.

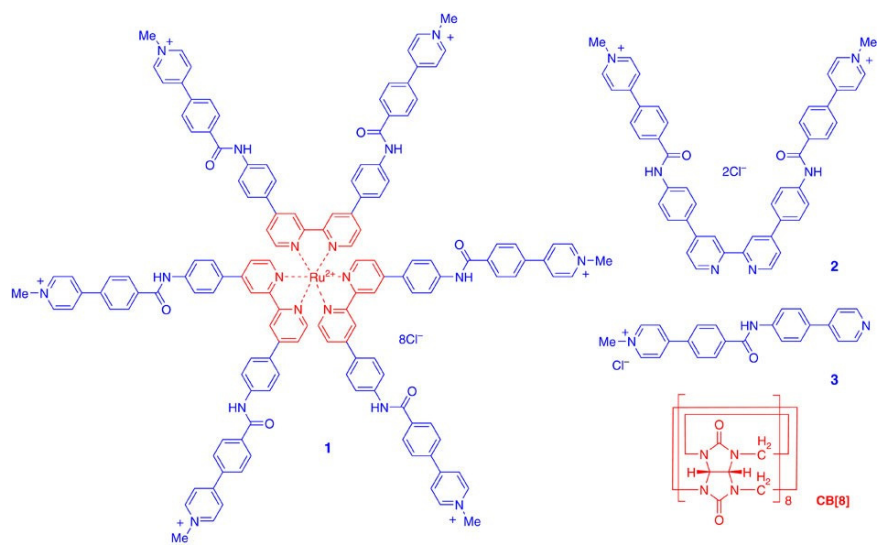

Figure 14. The building blocks used for the synthesis of the metal-cored supramolecular organic framework, SMOF-1. Reprinted with permission from [155]. Copyright (2016), Springer Nature. 
It is, however, important to note here that in the previous studies, the high-cost noble $\left[\mathrm{Ru}(\mathrm{bpy})_{3}\right]^{2+}$ and $\left[\operatorname{Ir}(\mathrm{ppy})_{2}(\mathrm{bpy})\right]^{+}$have been used as photosensitizers. The first noble metal-free photoactive POM@MOF catalyst was reported by Dolbecq et al. [145]. In this work, a redox active Co-based POM was embedded in a light-harvesting porphyrinic MOF, denoted as MOF-545, for the visible-light-driven oxidation of water (Figure 15) or, in other words, both the photosensitizer and the catalyst were incorporated into the same porous material. The authors observed that the $\mathrm{O}_{2}$ production started upon exposure to light and increased linearly over time, until a plateau was reached after $1 \mathrm{~h}$ of catalysis. The authors stated that the unique activity of this "three in one" photoactive catalyst was the result of (i) the immobilization of the porphyrin ligand in the MOF, which increased its oxidizing power, and (ii) the confinement of the Co-POM in the pores of MOF-545, which resulted in an increased stabilization of the POM catalytic sites. Nevertheless, the reuse of this POM@MOF catalyst was hampered due to a partial loss of the powder during centrifugation. To overcome this issue, the authors deposited a thin film of the latter POM@MOF on indium tin oxide, which served as a conducting support to allow better electronic transport, but also permitted easier reuse [146]. The films obtained through drop casting not only exhibited a significantly better performance in photocatalytic water oxidation (TON $=1600$ and $\mathrm{TOF}=0.467 \mathrm{~s}^{-1}$ ) in comparison to the POM@MOF in suspension $\left(\mathrm{TON}=70\right.$ and TOF $\left.=0.04 \mathrm{~s}^{-1}\right)$, but also outperformed the previously homogeneous $\mathrm{P}_{2} \mathrm{~W}_{18} \mathrm{Co}_{4}$-based photosystems (TON = 75) [162].

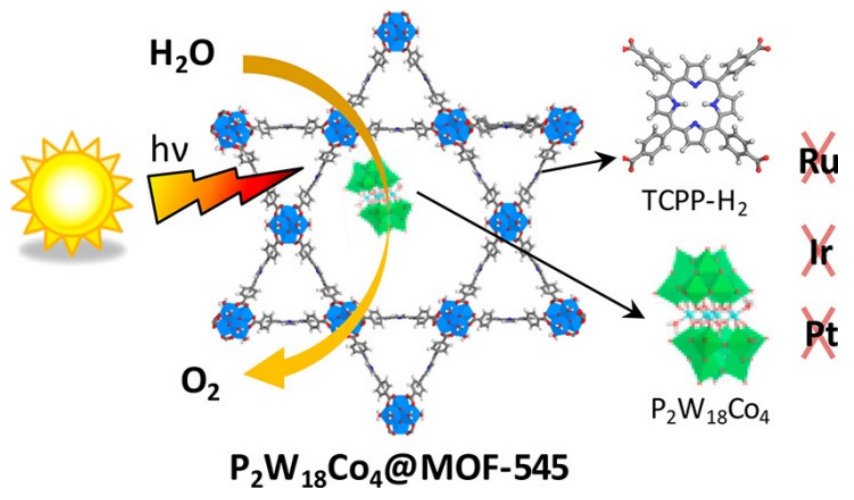

Figure 15. A fully noble metal-free POM@MOF catalyst for the photocatalytic oxidation of water. Reprinted with permission from [145]. Copyright (2018), American Chemistry Society.

However, it is important to note here that in the previously presented studies, a sacrificial donor or acceptor was required for the photocatalytic process. In a very recent work by Niu and co-workers, the assembling of a photosensitizer, electron donor, and acceptor into one single framework was reported [149]. For the synthesis of this Zn-based framework, the photosensitizer $N, N^{\prime}$-di(4-pyridyl)-1,4,5,8-naphthalenetetracarboxydiimide (DPNDI) was used as the organic ligand, while pyrrolidine-2-yl-imidazole and the $\left[\mathrm{BW}_{12} \mathrm{O}_{40}\right]^{5-}$ anion were introduced, respectively, as an electron donor and electron acceptor (see Figure 16). The resulting Zn-DPNDI-PYI catalyst was examined in the oxidative coupling of benzylamine, exhibiting a conversion of $99 \%$ after $16 \mathrm{~h}$ of reaction. This high activity was not only the result of the consecutive photo-induced electron transfer (conPET) process, but was also assigned to the long-lived charge separated state. 


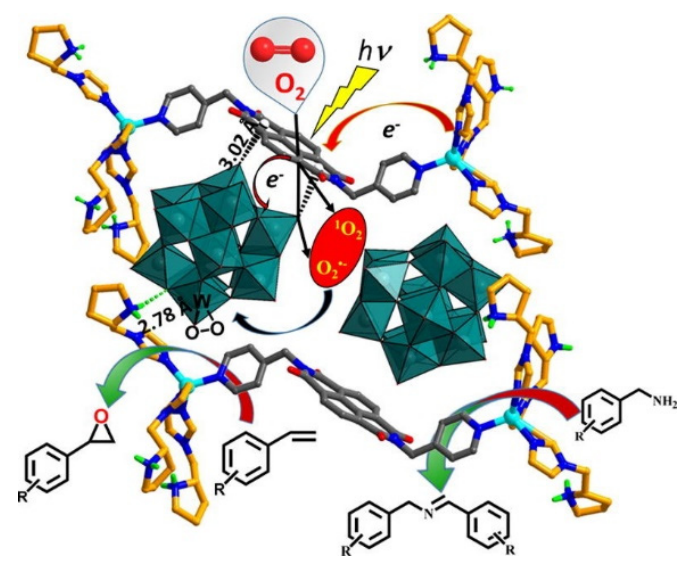

Figure 16. Zn-DPNDI-PYI as photocatalyst for the coupling of primary amines and oxidation of olefins with air under visible light. Reprinted from [149]. Copyright (2019), with permission from Elsevier.

\section{Summary and Outlook}

Metal-organic frameworks exhibiting well-defined cages, large surface areas, and a high thermal and chemical stability are excellent hosts for encapsulating polyoxometalates. More than 100 studies on such POM@MOF hybrids have appeared in the last decade. In this review, we mainly focused on the common synthetic aspects and catalytic applications of POM@MOF hybrids in organocatalysis, electrocatalysis, and photocatalysis. More specifically, the activity, recyclability, stability, and interesting synergetic functions of POM@MOF were discussed.

The size of the pores and the aperture of the pore windows are very critical parameters in the design of a POM@MOF. The embedding of POMs into MOFs not only allows the shortcomings of POMs to be overcome, but also ensures the use of the unique advantages of MOFs. The rise of POM@MOF systems is mainly attributed to the excellent dispersion and subsequent stability of the POM in the MOF host. The unique cages and windows and the tunable chemical environment of MOFs enable interesting interactions and synergic effects between POM and MOFs, thus creating excellent novel heterogeneous catalysts.

Although POM@MOF hybrid materials have made tremendous progress in recent years, many challenges still need to be addressed. First of all, the interaction between POMs and MOFs is often limited to weak electrostatic interactions, which can result in POM leaching during the catalysis. To this end, stronger interactions, such as covalent bonds between the MOF host and the encapsulated POM, would allow a further increase of the POM@MOF reusability in catalysis. Secondly, at this moment, there is still too much 'trial and error' involved to obtain a good control on the position and distribution of POMs inside MOF cages/channels. Thirdly, very little is known about the synergetic effects and electron transfer mechanism in catalytic reactions. To address this problem, theoretical calculations combined with in-situ and ex-situ characterization techniques would provide a better understanding of the synergetic effects and electron transfer mechanism. Finally, up until now, only some well-known archetypical POMs have been encapsulated in MOFs. New and innovative types of POMs (such as $\mathrm{V}$-centered POMs) with a proven excellent performance in oxidation and photocatalytic reactions should be combined with MOFs to further enhance the application range of these hybrids. We have no doubt that several exciting new (catalytic) applications will be reported in the next months and years in this strongly growing field of research.

Author Contributions: Conceptualization and supervision: P.V.D.V. Writing-review and editing: J.S., S.A., Y.-Y.L. and K.L. All authors have read and agreed to the published version of the manuscript.

Funding: This work was financially supported by Ghent University BOF doctoral grant 01D04318, the Research Foundation Flanders (FWO-Vlaanderen) grant no. G000117N, the International S\&T Cooperation Program of China (2016YFE0109800) and the China Scholarship Council (CSC). 
Conflicts of Interest: The authors declare no conflicts of interest.

\section{References}

1. Berzelius, J.J.A. Beitrag zur näheren kenntniss des molybdäns. Ann. Phys. 1826, 82, 369-392. [CrossRef]

2. Keggin, J.F. The structure and formula of 12-phosphotungstic acid. Proc. R. Soc. Lond. Ser. A 1934, 144, 75-100.

3. Omwoma, S.; Gore, C.T.; Ji, Y.C.; Hu, C.W.; Song, Y.F. Environmentally benign polyoxometalate materials. Coord. Chem. Rev. 2015, 286, 17-29. [CrossRef]

4. Cao, Y.W.; Chen, Q.Y.; Shen, C.R.; He, L. Polyoxometalate-based catalysts for $\mathrm{CO}_{2}$ conversion. Molecules 2019, 24, 2069. [CrossRef]

5. Misra, A.; Kozma, K.; Streb, C.; Nyman, M. Beyond charge balance: Counter-cations in polyoxometalate chemistry. Angew. Chem. Int. Ed. 2020, 59, 596-612. [CrossRef]

6. Huang, B.; Yang, D.H.; Han, B.H. Application of polyoxometalate derivatives in rechargeable batteries. J. Mater. Chem. A 2020, 8, 4593-4628. [CrossRef]

7. Zhai, L.; Li, H.L. Polyoxometalate-polymer hybrid materials as proton exchange membranes for fuel cell applications. Molecules 2019, 24, 3425. [CrossRef]

8. Liu, D.X.; Zou, D.T.; Zhu, H.L.; Zhang, J.Y. Mesoporous metal-organic frameworks: Synthetic strategies and emerging applications. Small 2018, 14, 1801454. [CrossRef]

9. Qin, J.S.; Yuan, S.; Lollar, C.; Pang, J.D.; Alsalme, A.; Zhou, H.C. Stable metal-organic frameworks as a host platform for catalysis and biomimetics. Chem. Commun. 2018, 54, 4231-4249. [CrossRef]

10. Bedia, J.; Muelas-Ramos, V.; Penas-Garzon, M.; Gomez-Aviles, A.; Rodriguez, J.J.; Belver, C. A review on the synthesis and characterization of metal organic frameworks for photocatalytic water purification. Catalysts 2019, 9, 52. [CrossRef]

11. Shen, X.; Pan, Y.; Sun, Z.H.; Liu, D.; Xu, H.J.; Yu, Q.; Trivedi, M.; Kumar, A.; Chen, J.X.; Liu, J.Q. Design of metal-organic frameworks for $\mathrm{pH}$-responsive drug delivery application. Mini Rev. Med. Chem. 2019, 19, 1644-1665. [CrossRef] [PubMed]

12. Yang, J.; Yang, Y.W. Metal-organic frameworks for biomedical applications. Small 2020, 16, 1906846-1906869. [CrossRef] [PubMed]

13. Amini, A.; Kazemi, S.; Safarifard, V. Metal-organic framework-based nanocomposites for sensing applications-A review. Polyhedron 2020, 177, 114260. [CrossRef]

14. Li, G.D.; Zhao, S.L.; Zhang, Y.; Tang, Z.Y. Metal-organic frameworks encapsulating active nanoparticles as emerging composites for catalysis: Recent progress and perspectives. Adv. Mater. 2018, 30, 1800702. [CrossRef] [PubMed]

15. Majewski, M.B.; Howarth, A.J.; Li, P.; Wasielewski, M.R.; Hupp, J.T.; Farha, O.K. Enzyme encapsulation in metal-organic frameworks for applications in catalysis. CrystEngComm 2017, 19, 4082-4091. [CrossRef]

16. Samaniyan, M.; Mirzaei, M.; Khajavian, R.; Eshtiagh-Hosseini, H.; Streb, C. Heterogeneous catalysis by polyoxometalates in metal-organic frameworks. ACS Catal. 2019, 9, 10174-10191. [CrossRef]

17. Fang, Y.; Powell, J.A.; Li, E.R.; Wang, Q.; Perry, Z.; Kirchon, A.; Yang, X.Y.; Xiao, Z.F.; Zhu, C.F.; Zhang, L.L.; et al. Catalytic reactions within the cavity of coordination cages. Chem. Soc. Rev. 2019, 48, 4707-4730. [CrossRef]

18. Ferey, G.; Mellot-Draznieks, C.; Serre, C.; Millange, F.; Dutour, J.; Surble, S.; Margiolaki, I. A chromium terephthalate-based solid with unusually large pore volumes and surface area. Science 2005, 309, 2040-2042. [CrossRef]

19. Liu, J.X.; Zhang, X.B.; Li, Y.L.; Huang, S.L.; Yang, G.Y. Polyoxometalate functionalized architectures. Coordin. Chem. Rev. 2020, 414, 213260-213275. [CrossRef]

20. Du, D.Y.; Qin, J.S.; Li, S.L.; Su, Z.M.; Lan, Y.Q. Recent advances in porous polyoxometalate-based metal-organic framework materials. Chem. Soc. Rev. 2014, 43, 4615-4632. [CrossRef]

21. Li, X.X.; Zhao, D.; Zheng, S.T. Recent advances in POM-organic frameworks and POM-organic polyhedra. Coordin. Chem. Rev. 2019, 397, 220-240. [CrossRef]

22. Chavan, S.; Vitillo, J.G.; Gianolio, D.; Zavorotynska, O.; Civalleri, B.; Jakobsen, S.; Nilsen, M.H.; Valenzano, L.; Lamberti, C.; Lillerud, K.P.; et al. $\mathrm{H}_{2}$ storage in isostructural UiO-67 and UiO-66 MOFs. Phys. Chem. Chem. Phys. 2012, 14, 1614-1626. [CrossRef] [PubMed] 
23. Cavka, J.H.; Jakobsen, S.; Olsbye, U.; Guillou, N.; Lamberti, C.; Bordiga, S.; Lillerud, K.P. A new zirconium inorganic building brick forming metal organic frameworks with exceptional stability. J. Am. Chem. Soc. 2008, 130, 13850-13851. [CrossRef] [PubMed]

24. Islamoglu, T.; Otake, K.; Li, P.; Buru, C.T.; Peters, A.W.; Akpinar, I.; Garibay, S.J.; Farha, O.K. Revisiting the structural homogeneity of NU-1000, a Zr-based metal-organic framework. CrystEngComm 2018, 20, 5913-5918. [CrossRef]

25. Luo, H.Z.; Zeng, Z.T.; Zeng, G.M.; Zhang, C.; Xiao, R.; Huang, D.L.; Lai, C.; Cheng, M.; Wang, W.J.; Xiong, W.P.; et al. Recent progress on metal-organic frameworks based- and derived-photocatalysts for water splitting. Chem. Eng. J. 2020, 383, 123196-123214. [CrossRef]

26. Park, K.S.; Ni, Z.; Cote, A.P.; Choi, J.Y.; Huang, R.D.; Uribe-Romo, F.J.; Chae, H.K.; O’Keeffe, M.; Yaghi, O.M. Exceptional chemical and thermal stability of zeolitic imidazolate frameworks. Proc. Natl. Acad. Sci. USA 2006, 103, 10186-10191. [CrossRef]

27. Horcajada, P.; Surble, S.; Serre, C.; Hong, D.Y.; Seo, Y.K.; Chang, J.S.; Greneche, J.M.; Margiolaki, I.; Ferey, G. Synthesis and catalytic properties of MIL-100(Fe), an iron(III) carboxylate with large pores. Chem. Commun. 2007, 2820-2822. [CrossRef]

28. Krungleviciute, V.; Lask, K.; Migone, A.D.; Lee, J.Y.; Li, J. Kinetics and equilibrium of gas adsorption on RPM1-Co and Cu-BTC metal-organic frameworks: Potential for gas separation applications. AIChE J. 2008, 54, 918-923. [CrossRef]

29. Naseri, E.; Khoshnavazi, R. Sandwich type polyoxometalates encapsulated into the mesoporous material: Synthesis, characterization and catalytic application in the selective oxidation of sulfides. RSC Adv. 2018, 8, 28249-28260. [CrossRef]

30. Juan-Alcañiz, J.; Ramos-Fernandez, E.V.; Lafont, U.; Gascon, J.; Kapteijn, F. Building MOF bottles around phosphotungstic acid ships: One-pot synthesis of bi-functional polyoxometalate-MIL-101 catalysts. J. Catal. 2010, 269, 229-241. [CrossRef]

31. Canioni, R.; Roch-Marchal, C.; Sécheresse, F.; Horcajada, P.; Serre, C.; Hardi-Dan, M.; Férey, G.; Grenèche, J.-M.; Lefebvre, F.; Chang, J.-S.; et al. Stable polyoxometalate insertion within the mesoporous metal organic framework MIL-100(Fe). J. Mater. Chem. A 2011, 21, 1226-1233. [CrossRef]

32. Marandi, A.; Tangestaninejad, S.; Moghadam, M.; Mirkhani, V.; Mechler, A.; Mohammadpoor-Baltork, I.; Zadehahmadi, F. Dodecatungstocobaltate heteropolyanion encapsulation into MIL-101(Cr) metal-organic framework scaffold provides a highly efficient heterogeneous catalyst for methanolysis of epoxides. Appl. Organomet. Chem. 2018, 32, 4065-4074. [CrossRef]

33. Wang, X.S.; Huang, Y.B.; Lin, Z.J.; Cao, R. Phosphotungstic acid encapsulated in the mesocages of amine-functionalized metal-organic frameworks for catalytic oxidative desulfurization. Dalton Trans. 2014, 43, 11950-11958. [CrossRef] [PubMed]

34. Abednatanzi, S.; Leus, K.; Derakhshandeh, P.G.; Nahra, F.; De Keukeleere, K.; Van Hecke, K.; Van Driessche, I.; Abbasi, A.; Nolan, S.P.; Der Voort, P.V. POM@IL-MOFs -Inclusion of POMs in ionic liquid modified MOFs to produce recyclable oxidation catalysts. Catal. Sci. Technol. 2017, 7, 1478-1487. [CrossRef]

35. Shiju, N.R.; Alberts, A.H.; Khalid, S.; Brown, D.R.; Rothenberg, G. Mesoporous silica with site-isolated amine and phosphotungstic acid groups: A solid catalyst with tunable antagonistic functions for one-pot tandem reactions. Angew. Chem. Int. Ed. 2011, 50, 9615-9619. [CrossRef] [PubMed]

36. Ramos-Fernandez, E.V.; Pieters, C.; Van der Linden, B.; Juan-Alcaniz, J.; Serra-Crespo, P.; Verhoeven, M.W.G.M.; Niemantsverdriet, H.; Gascon, J.; Kapteijn, F. Highly dispersed platinum in metal organic framework $\mathrm{NH}_{2}$-MIL-101(Al) containing phosphotungstic acid-Characterization and catalytic performance. J. Catal. 2012, 289, 42-52. [CrossRef]

37. Bromberg, L.; Su, X.; Hatton, T.A. Heteropolyacid-functionalized aluminum 2-aminoterephthalate metal-organic frameworks as reactive aldehyde sorbents and catalysts. ACS Appl. Mater. Interfaces 2013, 5, 5468-5477. [CrossRef]

38. Bajpe, S.R.; Kirschhock, C.E.; Aerts, A.; Breynaert, E.; Absillis, G.; Parac-Vogt, T.N.; Giebeler, L.; Martens, J.A. Direct observation of molecular-level template action leading to self-assembly of a porous framework. Chemistry 2010, 16, 3926-3932. [CrossRef]

39. Liu, X.; Luo, J.; Sun, T.; Yang, S. A simple approach to the preparation of $\mathrm{H}_{6} \mathrm{P}_{2} \mathrm{~W}_{18} \mathrm{O}_{62} / \mathrm{Cu}_{3}(\mathrm{BTC})_{2}(\mathrm{BTC}=$ 1,3,5-benzenetricarboxylate) and its catalytic performance in the synthesis of acetals/ketals. React. Kinet. Mech. Catal. 2015, 116, 159-171. [CrossRef] 
40. Wee, L.H.; Bajpe, S.R.; Janssens, N.; Hermans, I.; Houthoofd, K.; Kirschhock, C.E.; Martens, J.A. Convenient synthesis of $\mathrm{Cu}_{3}(\mathrm{BTC})_{2}$ encapsulated Keggin heteropolyacid nanomaterial for application in catalysis. Chem. Commun. 2010, 46, 8186-8193. [CrossRef]

41. Song, J.; Luo, Z.; Britt, D.K.; Furukawa, H.; Yaghi, O.M.; Hardcastle, K.I.; Hill, C.L. A multiunit catalyst with synergistic stability and reactivity: A polyoxometalate-metal organic framework for aerobic decontamination. J. Am. Chem. Soc. 2011, 133, 16839-16846. [CrossRef] [PubMed]

42. Liu, S.-M.; Zhang, Z.; Li, X.; Jia, H.; Ren, M.; Liu, S. Ti-substituted Keggin-type polyoxotungstate as proton and electron reservoir encaged into metal-organic framework for carbon dioxide photoreduction. Adv. Mater. Interfaces 2018, 5, 1801062. [CrossRef]

43. Sun, C.Y.; Liu, S.X.; Liang, D.D.; Shao, K.Z.; Ren, Y.H.; Su, Z.M. Highly stable crystalline catalysts based on a microporous metal-organic framework and polyoxometalates. J. Am. Chem.Soc. 2009, 131, 1883-1888. [CrossRef] [PubMed]

44. Huang, Z.; Yang, Z.; Hussain, M.Z.; Chen, B.; Jia, Q.; Zhu, Y.; Xia, Y. Polyoxometallates@zeoliticimidazolate-framework derived bimetallic tungsten-cobalt sulfide/porous carbon nanocomposites as efficient bifunctional electrocatalysts for hydrogen and oxygen evolution. Electrochim. Acta 2020, 330, 135335. [CrossRef]

45. Malkar, R.S.; Yadav, G.D. Synthesis of cinnamyl benzoate over novel heteropoly acid encapsulated ZIF-8. Appl. Catal. A: Gen. 2018, 560, 54-65. [CrossRef]

46. Jeon, Y.; Chi, W.S.; Hwang, J.; Kim, D.H.; Kim, J.H.; Shul, Y.G. Core-shell nanostructured heteropoly acid-functionalized metal-organic frameworks: Bifunctional heterogeneous catalyst for efficient biodiesel production. Appl. Catal. B Environ. 2019, 242, 51-59. [CrossRef]

47. Kong, X.J.; Lin, Z.; Zhang, Z.M.; Zhang, T.; Lin, W. Hierarchical integration of photosensitizing metal-organic frameworks and nickel-containing polyoxometalates for efficient visible-light-driven hydrogen evolution. Angew. Chem. Int. Ed. 2016, 55, 6411-6416. [CrossRef]

48. Zhong, X.; Lu, Y.; Luo, F.; Liu, Y.; Li, X.; Liu, S. A nanocrystalline POM@MOFs catalyst for the degradation of phenol: Effective cooperative catalysis by metal nodes and POM guests. Eur. J. Chem. 2018, 24, 3045-3051. [CrossRef]

49. Li, G.; Zhang, K.; Li, C.; Gao, R.; Cheng, Y.; Hou, L.; Wang, Y. Solvent-free method to encapsulate polyoxometalate into metal-organic frameworks as efficient and recyclable photocatalyst for harmful sulfamethazine degrading in water. Appl. Catal. B Environ. 2019, 245, 753-759. [CrossRef]

50. Granadeiro, C.M.; Barbosa, A.D.S.; Ribeiro, S.; Santos, I.C.M.S.; De Castro, B.; Cunha-Silva, L.; Balula, S.S. Oxidative catalytic versatility of a trivacant polyoxotungstate incorporated into MIL-101(Cr). Catal. Sci. Technol. 2014, 4, 1416-1425. [CrossRef]

51. Ribeiro, S.; Barbosa, A.D.S.; Gomes, A.C.; Pillinger, M.; Gonçalves, I.S.; Cunha-Silva, L.; Balula, S.S. Catalytic oxidative desulfurization systems based on Keggin phosphotungstate and metal-organic framework MIL-101. Fuel Process. Technol. 2013, 116, 350-357. [CrossRef]

52. Hu, X.F.; Lu, Y.K.; Dai, F.N.; Liu, C.G.; Liu, Y.Q. Host-guest synthesis and encapsulation of phosphotungstic acid in MIL-101 via "bottle around ship": An effective catalyst for oxidative desulfurization. Micropor. Mesopor. Mat. 2013, 170, 36-44. [CrossRef]

53. Fazaeli, R.; Aliyan, H.; Masoudinia, M.; Heidari4, Z. Building MOF bottles (MIL-101 Family as heterogeneous single-site catalysts) around $\mathrm{H}_{3} \mathrm{PW}_{12} \mathrm{O}_{40}$ ships: An efficient catalyst for selective oxidation of sulfides to sulfoxides and sulfones. J. Mater. Chem. Eng. 2014, 2, 46-55.

54. Sun, M.; Chen, W.-C.; Zhao, L.; Wang, X.-L.; Su, Z.-M. A PTA@MIL-101(Cr)-diatomite composite as catalyst for efficient oxidative desulfurization. Inorg. Chem. Commun. 2018, 87, 30-35. [CrossRef]

55. Julião, D.; Gomes, A.C.; Pillinger, M.; Cunha-Silva, L.; De Castro, B.; Gonçalves, I.S.; Balula, S.S. Desulfurization of model diesel by extraction/oxidation using a zinc-substituted polyoxometalate as catalyst under homogeneous and heterogeneous (MIL-101(Cr) encapsulated) conditions. Fuel Process. Technol. 2015, 131, 78-86. [CrossRef]

56. Julião, D.; Gomes, A.C.; Pillinger, M.; Valença, R.; Ribeiro, J.C.; De Castro, B.; Gonçalves, I.S.; Cunha Silva, L.; Balula, S.S. Zinc-substituted polyoxotungstate@amino-MIL-101(Al)_An efficient catalyst for the sustainable desulfurization of model and real diesels. Eur. J. Inorg. Chem. 2016, 2016, 5114-5122. [CrossRef] 
57. Ribeiro, S.; Granadeiro, C.M.; Silva, P.; Almeida Paz, F.A.; De Biani, F.F.; Cunha-Silva, L.; Balula, S.S. An efficient oxidative desulfurization process using terbium-polyoxometalate@MIL-101(Cr). Catal. Sci. Technol. 2013, 3, 2404-2414. [CrossRef]

58. Granadeiro, C.M.; Nogueira, L.S.; Julião, D.; Mirante, F.; Ananias, D.; Balula, S.S.; Cunha-Silva, L. Influence of a porous MOF support on the catalytic performance of Eu-polyoxometalate based materials: Desulfurization of a model diesel. Catal. Sci. Technol. 2016, 6, 1515-1522. [CrossRef]

59. Granadeiro, C.M.; Barbosa, A.D.S.; Silva, P.; Paz, F.A.A.; Saini, V.K.; Pires, J.; De Castro, B.; Balula, S.S.; Cunha-Silva, L. Monovacant polyoxometalates incorporated into MIL-101(Cr): Novel heterogeneous catalysts for liquid phase oxidation. Appl. Catal. A Gen. 2013, 453, 316-326. [CrossRef]

60. Wang, X.-S.; Li, L.; Liang, J.; Huang, Y.-B.; Cao, R. Boosting oxidative desulfurization of model and real gasoline over phosphotungstic acid encapsulated in metal-organic frameworks: The window size matters. ChemCatChem 2017, 9, 971-979. [CrossRef]

61. Ni, X.-L.; Liu, J.; Liu, Y.-Y.; Leus, K.; Depauw, H.; Wang, A.-J.; Van Der Voort, P.; Zhang, J.; Hu, Y.-K. Synthesis, characterization and catalytic performance of Mo based metal- organic frameworks in the epoxidation of propylene by cumene hydroperoxide. Chin. Chem. Lett. 2017, 28, 1057-1061. [CrossRef]

62. Maksimchuk, N.V.; Timofeeva, M.N.; Melgunov, M.S.; Shmakov, A.N.; Chesalov, Y.A.; Dybtsev, D.N.; Fedin, V.P.; Kholdeeva, O.A. Heterogeneous selective oxidation catalysts based on coordination polymer MIL-101 and transition metal-substituted polyoxometalates. J. Catal. 2008, 257, 315-323. [CrossRef]

63. Saedi, Z.; Tangestaninejad, S.; Moghadam, M.; Mirkhani, V.; Mohammadpoor-Baltork, I. The effect of encapsulated Zn-POM on the catalytic activity of MIL-101 in the oxidation of alkenes with hydrogen peroxide. J. Coord. Chem. 2012, 65, 463-473. [CrossRef]

64. Maksimchuk, N.V.; Kovalenko, K.A.; Arzumanov, S.S.; Chesalov, Y.A.; Melgunov, M.S.; Stepanov, A.G.; Fedin, V.P.; Kholdeeva, O.A. Hybrid polyoxotungstate/MIL-101 materials: Synthesis, characterization, and catalysis of $\mathrm{H}_{2} \mathrm{O}_{2}$-based alkene epoxidation. Inorg. Chem. 2010, 49, 2920-2930. [CrossRef] [PubMed]

65. Balula, S.S.; Granadeiro, C.M.; Barbosa, A.D.S.; Santos, I.C.M.S.; Cunha-Silva, L. Multifunctional catalyst based on sandwich-type polyoxotungstate and MIL-101 for liquid phase oxidations. Catal. Today 2013, 210, 142-148. [CrossRef]

66. Tong, J.; Wang, W.; Su, L.; Li, Q.; Liu, F.; Ma, W.; Lei, Z.; Bo, L. Highly selective oxidation of cyclohexene to 2-cyclohexene-1-one over polyoxometalate/metal-organic framework hybrids with greatly improved performances. Catal. Sci. Technol. 2017, 7, 222-230. [CrossRef]

67. Ding, J.-W.; Wang, R. A new green system of HPW@MOFs catalyzed desulfurization using $\mathrm{O}_{2}$ as oxidant. Chin. Chem. Lett. 2016, 27, 655-658. [CrossRef]

68. Rafiee, E.; Nobakht, N. Keggin type heteropoly acid, encapsulated in metal-organic framework: A heterogeneous and recyclable nanocatalyst for selective oxidation of sulfides and deep desulfurization of model fuels. J. Mol. Catal. A Chem. 2015, 398, 17-25. [CrossRef]

69. Babahydari, A.K.; Fareghi-Alamdari, R.; Hafshejani, S.M.; Rudbari, H.A.; Farsani, M.R. Heterogeneous oxidation of alcohols with hydrogen peroxide catalyzed by polyoxometalate metal-organic framework. J. Iran. Chem. Soc. 2016, 13, 1463-1470. [CrossRef]

70. Zhu, J.; Shen, M.-N.; Zhao, X.-J.; Wang, P.-C.; Lu, M. Polyoxometalate-based metal-organic frameworks as catalysts for the selective oxidation of alcohols in micellar systems. ChemPlusChem 2014, 79, 872-878. [CrossRef]

71. Wang, S.; Liu, Y.; Zhang, Z.; Li, X.; Tian, H.; Yan, T.; Zhang, X.; Liu, S.; Sun, X.; Xu, L.; et al. One-step template-free fabrication of ultrathin mixed-valence polyoxovanadate-incorporated metal organic framework nanosheets for highly efficient selective oxidation catalysis in air. ACS Appl. Mater. Interfaces 2019, 11, 12786-12796. [CrossRef] [PubMed]

72. Yang, X.L.; Qiao, L.M.; Dai, W.L. One-pot synthesis of a hierarchical microporous-mesoporous phosphotungstic acid-HKUST-1 catalyst and its application in the selective oxidation of cyclopentene to glutaraldehyde. Chin. J. Catal. 2015, 36, 1875-1885. [CrossRef]

73. Ke, F.; Guo, F.; Yu, J.; Yang, Y.Q.; He, Y.; Chang, L.Z.; Wan, X.C. Highly site-selective epoxidation of polyene catalyzed by metal-organic frameworks assisted by polyoxometalate. J. Inorg. Organomet. Polym. Mater. 2017, 27, 843-849. [CrossRef]

74. Yang, H.; Li, J.; Wang, L.Y.; Dai, W.; Lv, Y.; Gao, S. Exceptional activity for direct synthesis of phenol from benzene over PMoV@MOF with $\mathrm{O}_{2}$. Catal. Commun. 2013, 35, 101-104. [CrossRef] 
75. Liu, Y.W.; Liu, S.M.; Liu, S.X.; Liang, D.D.; Li, S.J.; Tang, Q.; Wang, X.Q.; Miao, J.; Shi, Z.; Zheng, Z.P. Facile synthesis of a nanocrystalline metal-organic framework impregnated with a phosphovanadomolybdate and its remarkable catalytic performance in ultradeep oxidative desulfurization. Chem CatChem 2013, 5, 3086-3091. [CrossRef]

76. Li, S.-W.; Gao, R.-M.; Zhao, J.-S. Deep oxidative desulfurization of fuel catalyzed by modified heteropolyacid: The comparison performance of three kinds of ionic liquids. ACS Sustain. Chem. Eng. 2018, 6, 15858-15866. [CrossRef]

77. Li, S.W.; Li, J.R.; Jin, Q.P.; Yang, Z.; Zhang, R.L.; Gao, R.M.; Zhao, J.S. Preparation of mesoporous Cs-PO7M@MOF-199@MCM-41 under two different synthetic methods for a highly oxidesulfurization of dibenzothiophene. J. Hazard. Mater. 2017, 337, 208-216. [CrossRef] [PubMed]

78. Gao, Y.; Lv, Z.; Gao, R.; Zhang, G.; Zheng, Y.; Zhao, J. Oxidative desulfurization process of model fuel under molecular oxygen by polyoxometalate loaded in hybrid material CNTs@MOF-199 as catalyst. J. Hazard. Mater. 2018, 359, 258-265. [CrossRef]

79. Yang, H.; Li, J.; Zhang, H.Y.; Lv, Y.; Gao, S. Facile synthesis of POM@MOF embedded in SBA-15 as a steady catalyst for the hydroxylation of benzene. Micropor. Mesopor. Mat. 2014, 195, 87-91. [CrossRef]

80. Zhang, Y.; Zhang, W.; Zhang, J.; Dong, Z.; Zhang, X.; Ding, S. One-pot synthesis of cup-like ZSM-5 zeolite and its excellent oxidative desulfurization performance. RSC Adv. 2018, 8, 31979-31983. [CrossRef]

81. Tian, H.R.; Liu, Y.W.; Zhang, Z.; Liu, S.M.; Dang, T.Y.; Li, X.H.; Sun, X.W.; Lu, Y.; Liu, S.X. A multicentre synergistic polyoxometalate-based metal-organic framework for one-step selective oxidative cleavage of beta-O-4 lignin model compounds. Green Chem. 2020, 22, 248-255. [CrossRef]

82. Salomon, W.; Roch-Marchal, C.; Mialane, P.; Rouschmeyer, P.; Serre, C.; Haouas, M.; Taulelle, F.; Yang, S.; Ruhlmann, L.; Dolbecq, A. Immobilization of polyoxometalates in the Zr-based metal organic framework UiO-67. Chem. Commun. 2015, 51, 2972-2975. [CrossRef] [PubMed]

83. Yang, X.-L.; Qiao, L.-M.; Dai, W.-L. Phosphotungstic acid encapsulated in metal-organic framework UiO-66: An effective catalyst for the selective oxidation of cyclopentene to glutaraldehyde. Micropor. Mesopor. Mat. 2015, 211, 73-81. [CrossRef]

84. Song, X.; Hu, D.; Yang, X.; Zhang, H.; Zhang, W.; Li, J.; Jia, M.; Yu, J. Polyoxomolybdic cobalt encapsulated within Zr-based metal-organic frameworks as efficient heterogeneous catalysts for olefins epoxidation. ACS Sustain. Chem. Eng. 2019, 7, 3624-3631. [CrossRef]

85. Buru, C.T.; Wasson, M.C.; Farha, O.K. $\mathrm{H}_{5} \mathrm{PV}_{2} \mathrm{Mo}_{10} \mathrm{O}_{40}$ polyoxometalate encapsulated in NU-1000 metal-organic framework for aerobic oxidation of a mustard gas simulant. ACS Appl. Nano. Mater. 2019, 3, 658-664. [CrossRef]

86. Buru, C.T.; Platero-Prats, A.E.; Chica, D.G.; Kanatzidis, M.G.; Chapman, K.W.; Farha, O.K. Thermally induced migration of a polyoxometalate within a metal-organic framework and its catalytic effects. J. Mater. Chem. A 2018, 6, 7389-7394. [CrossRef]

87. Buru, C.T.; Li, P.; Mehdi, B.L.; Dohnalkova, A.; Platero-Prats, A.E.; Browning, N.D.; Chapman, K.W.; Hupp, J.T.; Farha, O.K. Adsorption of a catalytically accessible polyoxometalate in a mesoporous channel-type metal-organic framework. Chem. Mater. 2017, 29, 5174-5181. [CrossRef]

88. Hao, X.L.; Ma, Y.Y.; Zang, H.Y.; Wang, Y.H.; Li, Y.G.; Wang, E.B. A polyoxometalate-encapsulating cationic metal-organic framework as a heterogeneous catalyst for desulfurization. Eur. J. Chem. 2015, 21, 3778-3784. [CrossRef]

89. Roy, S.; Vemuri, V.; Maiti, S.; Manoj, K.S.; Subbarao, U.; Peter, S.C. Two Keggin-based isostructural POMOF hybrids: Synthesis, crystal structure, and catalytic properties. Inorg. Chem. 2018, 57, 12078-12092. [CrossRef]

90. Ma, Y.Y.; Peng, H.Y.; Liu, J.N.; Wang, Y.H.; Hao, X.L.; Feng, X.J.; Khan, S.U.; Tan, H.Q.; Li, Y.G. Polyoxometalate-based metal-organic frameworks for selective oxidation of aryl alkenes to aldehydes. Inorg. Chem. 2018, 57, 4109-4116. [CrossRef]

91. Li, D.D.; Ma, X.Y.; Wang, Q.Z.; Ma, P.T.; Niu, J.Y.; Wang, J.P. Copper-containing polyoxometalate-based metal-organic frameworks as highly efficient heterogeneous catalysts toward selective oxidation of alkylbenzenes. Inorg. Chem. 2019, 58, 15832-15840. [CrossRef] [PubMed]

92. Li, D.D.; Xu, Q.F.; Li, Y.G.; Qiu, Y.T.; Ma, P.T.; Niu, J.Y.; Wang, J.P. A Stable polyoxometalate-based metal-organic framework as highly efficient heterogeneous catalyst for oxidation of alcohols. Inorg. Chem. 2019, 58, 4945-4953. [CrossRef] [PubMed] 
93. Ghahramaninezhad, M.; Pakdel, F.; Niknam Shahrak, M. Boosting oxidative desulfurization of model fuel by POM-grafting ZIF-8 as a novel and efficient catalyst. Polyhedron 2019, 170, 364-372. [CrossRef]

94. Li, Y.Q.; Gao, Q.; Zhang, L.J.; Zhou, Y.S.; Zhong, Y.X.; Ying, Y.; Zhang, M.C.; Huang, C.Q.; Wang, Y.A. $\mathrm{H}_{5} \mathrm{PV}_{2} \mathrm{Mo}_{10} \mathrm{O}_{40}$ encapsulated in MIL-101(Cr): Facile synthesis and characterization of rationally designed composite materials for efficient decontamination of sulfur mustardt. Dalton Trans. 2018, 47, 6394-6403. [CrossRef]

95. Malkar, R.S.; Daly, H.; Hardacre, C.; Yadav, G.D. Aldol condensation of 5-hydroxymethylfurfural to fuel precursor over novel aluminum exchanged-DTP@ZIF-8. ACS Sustain. Chem. Eng. 2019, 7, 16215-16224. [CrossRef]

96. Saikia, M.; Bhuyan, D.; Saikia, L. Keggin type phosphotungstic acid encapsulated chromium (III) terephthalate metal organic framework as active catalyst for Biginelli condensation. Appl. Catal. A Gen. 2015, 505, 501-506. [CrossRef]

97. Deng, Q.; Nie, G.; Pan, L.; Zou, J.-J.; Zhang, X.; Wang, L. Highly selective self-condensation of cyclic ketones using MOF-encapsulating phosphotungstic acid for renewable high-density fuel. Green Chem. 2015, 17, 4473-4481. [CrossRef]

98. Bromberg, L.; Diao, Y.; Wu, H.; Speakman, S.A.; Hatton, T.A. Chromium(III) terephthalate metal organic framework (MIL-101): HF-free synthesis, structure, polyoxometalate composites, and catalytic properties. Chem. Mater. 2012, 24, 1664-1675. [CrossRef]

99. Bromberg, L.; Hatton, T.A. Aldehyde-alcohol reactions catalyzed under mild conditions by chromium(III) terephthalate metal organic framework (MIL-101) and phosphotungstic acid composites. ACS Appl. Mater. Interfaces 2011, 3, 4756-4764. [CrossRef]

100. Chen, M.; Yan, J.Q.; Tan, Y.; Li, Y.F.; Wu, Z.M.; Pan, L.S.; Liu, Y.J. Hydroxyalkylation of phenol with formaldehyde to bisphenol $\mathrm{F}$ catalyzed by Keggin phosphotungstic acid encapsulated in metal-organic frameworks MIL-100(Fe or Cr) and MIL-101(Fe or Cr). Ind. Eng. Chem. Res. 2015, 54, 11804-11813. [CrossRef]

101. Nobakht, N.; Faramarzi, M.A.; Shafiee, A.; Khoobi, M.; Rafiee, E. Polyoxometalate-metal organic framework-lipase: An efficient green catalyst for synthesis of benzyl cinnamate by enzymatic esterification of cinnamic acid. Int. J. Biol. Macromol. 2018, 113, 8-19. [CrossRef] [PubMed]

102. Wee, L.H.; Janssens, N.; Bajpe, S.R.; Kirschhock, C.E.A.; Martens, J.A. Heteropolyacid encapsulated in $\mathrm{Cu}_{3}(\mathrm{BTC})_{2}$ nanocrystals: An effective esterification catalyst. Catal. Today 2011, 171, 275-280. [CrossRef]

103. Guo, T.M.; Qiu, M.; Qi, X.H. Selective conversion of biomass-derived levulinic acid to ethyl levulinate catalyzed by metal organic framework (MOF)-supported polyoxometalates. Appl. Catal. A: Gen. 2019, 572, 168-175. [CrossRef]

104. Zhang, Q.Y.; Yang, T.T.; Liu, X.F.; Yue, C.Y.; Ao, L.F.; Deng, T.L.; Zhang, Y.T. Heteropoly acid-encapsulated metal-organic framework as a stable and highly efficient nanocatalyst for esterification reaction. RSC Adv. 2019, 9, 16357-16365. [CrossRef]

105. Marandi, A.; Bahadori, M.; Tangestaninejad, S.; Moghadam, M.; Mirkhani, V.; Mohammadpoor-Baltork, I.; Frohnhoven, R.; Mathur, S.; Sandleben, A.; Klein, A. Cycloaddition of $\mathrm{CO}_{2}$ with epoxides and esterification reactions using the porous redox catalyst Co-POM@MIL-101(Cr). New J. Chem. 2019, 43, 15585-15595. [CrossRef]

106. Zhu, J.; Wang, P.-C.; Lu, M. Study on the one-pot oxidative esterification of glycerol with MOF supported polyoxometalates as catalyst. Catal. Sci. Technol. 2015, 5, 3383-3393. [CrossRef]

107. Zhang, Q.Y.; Liu, X.F.; Yang, T.T.; Yue, C.Y.; Pu, Q.L.; Zhang, Y.T. Facile synthesis of polyoxometalates tethered to post Fe-BTC frameworks for esterification of free fatty acids to biodiesel. RSC Adv. 2019, 9, 8113-8120. [CrossRef]

108. Zhang, F.M.; Jin, Y.; Shi, J.; Zhong, Y.J.; Zhu, W.D.; El-Shall, M.S. Polyoxometalates confined in the mesoporous cages of metal-organic framework MIL-100(Fe): Efficient heterogeneous catalysts for esterification and acetalization reactions. Chem. Eng. J. 2015, 269, 236-244. [CrossRef]

109. Janssens, N.; Wee, L.H.; Bajpe, S.; Breynaert, E.; Kirschhock, C.E.A.; Martens, J.A. Recovery and reuse of heteropolyacid catalyst in liquid reaction medium through reversible encapsulation in $\mathrm{Cu}_{3}(\mathrm{BTC})_{2}$ metal-organic framework. Chem. Sci. 2012, 3, 1847-1850. [CrossRef]

110. Zang, Y.D.; Shi, J.; Zhao, X.M.; Kong, L.C.; Zhang, F.M.; Zhong, Y.J. Highly stable chromium(III) terephthalate metal organic framework (MIL-101) encapsulated 12-tungstophosphoric heteropolyacid as a water-tolerant solid catalyst for hydrolysis and esterification. React. Kinet. Mech. Cat. 2013, 109, 77-89. [CrossRef] 
111. Nikseresht, A.; Daniyali, A.; Ali-Mohammadi, M.; Afzalinia, A.; Mirzaie, A. Ultrasound-assisted biodiesel production by a novel composite of $\mathrm{Fe}(\mathrm{III})$-based MOF and phosphotangestic acid as efficient and reusable catalyst. Ultrason. Sonochem. 2017, 37, 203-207. [CrossRef] [PubMed]

112. Wan, H.; Chen, C.; Wu, Z.W.; Que, Y.G.; Feng, Y.; Wang, W.; Wang, L.; Guan, G.F.; Liu, X.Q. Encapsulation of heteropolyanion-based ionic liquid within the metal-organic framework MIL-100(Fe) for biodiesel production. ChemCatChem 2015, 7, 441-449. [CrossRef]

113. Liu, Y.W.; Liu, S.M.; He, D.F.; Li, N.; Ji, Y.J.; Zheng, Z.P.; Luo, F.; Liu, S.X.; Shi, Z.; Hu, C.W. Crystal facets make a profound difference in polyoxometalate-containing metal-organic frameworks as catalysts for biodiesel production. J. Am. Chem. Soc. 2015, 137, 12697-12703. [CrossRef] [PubMed]

114. Xie, W.; Wan, F. Immobilization of polyoxometalate-based sulfonated ionic liquids on UiO-66-2COOH metal-organic frameworks for biodiesel production via one-pot transesterification-esterification of acidic vegetable oils. Chem. Eng. J. 2019, 365, 40-50. [CrossRef]

115. Chen, L.N.; Zhang, X.B.; Zhou, J.H.; Xie, Z.X.; Kuang, Q.; Zheng, L.S. A nano-reactor based on $\mathrm{PtNi} @$ metal-organic framework composites loaded with polyoxometalates for hydrogenation-esterification tandem reactions. Nanoscale 2019, 11, 3292-3299. [CrossRef]

116. Zhang, Y.M.; Degirmenci, V.; Li, C.; Hensen, E.J.M. Phosphotungstic acid encapsulated in metal-organic framework as catalysts for carbohydrate dehydration to 5-Hydroxymethylfurfural. ChemSusChem 2011, 4, 59-64. [CrossRef]

117. Wang, Z.H.; Chen, Q.W. Conversion of 5-hydroxymethylfurfural into 5-ethoxymethylfurfural and ethyl levulinate catalyzed by MOF-based heteropolyacid materials. Green Chem. 2016, 18, 5884-5889. [CrossRef]

118. Xie, W.L.; Wan, F. Biodiesel production from acidic oils using polyoxometalate-based sulfonated ionic liquids functionalized metal-organic frameworks. Catal. Lett. 2019, 149, 2916-2929. [CrossRef]

119. Cai, X.X.; Xu, Q.H.; Tu, G.M.; Fu, Y.H.; Zhang, F.M.; Zhu, W.D. Synergistic catalysis of ruthenium nanoparticles and polyoxometalate integrated within single UiO-66 microcrystals for boosting the efficiency of methyl levulinate to gamma-valerolactone. Front. Chem. 2019, 7, 24-34. [CrossRef]

120. Chen, J.; Wang, S.; Huang, J.; Chen, L.; Ma, L.; Huang, X. Conversion of cellulose and cellobiose into sorbitol catalyzed by ruthenium supported on a polyoxometalate/metal-organic framework hybrid. ChemSusChem 2013, 6, 2213. [CrossRef]

121. Wee, L.H.; Wiktor, C.; Turner, S.; Vanderlinden, W.; Janssens, N.; Bajpe, S.R.; Houthoofd, K.; Van Tendeloo, G.; De Feyter, S.; Kirschhock, C.E.A.; et al. Copper benzene tricarboxylate metal-organic framework with wide permanent mesopores stabilized by Keggin polyoxometallate ions. J. Am. Chem. Soc. 2012, 134, 10911-10919. [CrossRef] [PubMed]

122. Wee, L.H.; Bonino, F.; Lamberti, C.; Bordiga, S.; Martens, J.A. Cr-MIL-101 encapsulated Keggin phosphotungstic acid as active nanomaterial for catalysing the alcoholysis of styrene oxide. Green Chem. 2014, 16, 1351-1357. [CrossRef]

123. Ma, F.J.; Liu, S.X.; Sun, C.Y.; Liang, D.D.; Ren, G.J.; Wei, F.; Chen, Y.G.; Su, Z.M. A sodalite-type porous metal-organic framework with polyoxometalate templates: Adsorption and decomposition of dimethyl methylphosphonate. J. Am. Chem. Soc. 2011, 133, 4178-4181. [CrossRef] [PubMed]

124. Ma, F.J.; Liu, S.X.; Ren, G.J.; Liang, D.D.; Sha, S. A hybrid compound based on porous metal-organic frameworks and polyoxometalates: NO adsorption and decomposition. Inorg. Chem. Commun. 2012, 22, 174-177. [CrossRef]

125. Liang, D.D.; Liu, S.X.; Ma, F.J.; Wei, F.; Chen, Y.G. A crystalline catalyst based on a porous metal-organic framework and 12-tungstosilicic acid: Particle size control by hydrothermal synthesis for the formation of dimethyl ether. Adv. Synth. Catal. 2011, 353, 733-742. [CrossRef]

126. Micek-Ilnicka, A.; Gil, B. Heteropolyacid encapsulation into the MOF: Influence of acid particles distribution on ethanol conversion in hybrid nanomaterials. Dalton Trans. 2012, 41, 12624-12629. [CrossRef]

127. Juliao, D.; Barbosa, A.D.S.; Peixoto, A.F.; Freire, C.; De Castro, B.; Balula, S.S.; Cunha-Silva, L. Improved catalytic performance of porous metal-organic frameworks for the ring opening of styrene oxide. CrystEngComm 2017, 19, 4219-4226. [CrossRef]

128. Shah, W.A.; Noureen, L.; Nadeem, M.A.; Kogerler, P. Encapsulation of Keggin-type manganesepolyoxomolybdates in MIL-100 (Fe) for efficient reduction of p-nitrophenol. J. Solid State Chem. 2018, 268, 75-82. [CrossRef] 
129. Ullah, L.; Zhao, G.Y.; Xu, Z.C.; He, H.Y.; Usman, M.; Zhang, S.J. 12-Tungstophosphoric acid niched in Zr-based metal-organic framework: A stable and efficient catalyst for Friedel-Crafts acylation. Sci. China Chem. 2018, 61, 402-411. [CrossRef]

130. Khder, A.S.; Hassan, H.M.A.; El-Shall, M.S. Metal-organic frameworks with high tungstophosphoric acid loading as heterogeneous acid catalysts. Appl. Catal. A Gen. 2014, 487, 110-118. [CrossRef]

131. Xie, W.L.; Yang, X.L.; Hu, P.T. $\mathrm{Cs}_{2.5} \mathrm{H}_{0.5} \mathrm{PW}_{12} \mathrm{O}_{40}$ Encapsulated in metal-organic framework UiO-66 as heterogeneous catalysts for acidolysis of soybean oil. Catal. Lett. 2017, 147, 2772-2782. [CrossRef]

132. Lu, B.B.; Yang, J.; Che, G.B.; Pei, W.Y.; Ma, J.F. Highly stable copper(I)-based metal-organic framework assembled with resorcin[4]arene and polyoxometalate for efficient heterogeneous catalysis of azide-alkyne "Click" reaction. ACS Appl. Mater. Interfaces 2018, 10, 2628-2636. [CrossRef] [PubMed]

133. Ahn, S.; Nauert, S.L.; Buru, C.T.; Rimoldi, M.; Choi, H.; Schweitzer, N.M.; Hupp, J.T.; Farha, O.K.; Notestein, J.M. Pushing the limits on metal-organic frameworks as a catalyst support: NU-1000 supported tungsten catalysts for o-xylene isomerization and disproportionation. J. Am. Chem. Soc. 2018, 140, 8535-8543. [CrossRef] [PubMed]

134. Sartipi, S.; Romero, M.J.V.; Rozhko, E.; Que, Z.Y.; Stil, H.A.; De With, J.; Kapteijn, F.; Gascon, J. Dynamic release-immobilization of a homogeneous rhodium hydroformylation catalyst by a polyoxometalate metal-organic framework composite. ChemCatChem 2015, 7, 3243-3247. [CrossRef]

135. Taherimehr, M.; Van de Voorde, B.; Wee, L.H.; Martens, J.A.; De Vos, D.E.; Pescarmona, P.P. Strategies for enhancing the catalytic performance of metal-organic frameworks in the fixation of $\mathrm{CO}_{2}$ into cyclic carbonates. ChemSusChem 2017, 10, 1283-1291. [CrossRef]

136. Han, J.Y.; Wang, D.P.; Du, Y.H.; Xi, S.B.; Chen, Z.; Yin, S.M.; Zhou, T.H.; Xu, R. Polyoxometalate immobilized in MIL-101(Cr) as an efficient catalyst for water oxidation. Appl. Catal. A Gen. 2016, 521, 83-89. [CrossRef]

137. Mukhopadhyay, S.; Debgupta, J.; Singh, C.; Kar, A.; Das, S.K. A Keggin polyoxometalate shows water oxidation activity at neutral pH: POM@ZIF-8, an efficient and robust electrocatalyst. Angew. Chem. Int. Ed. 2018, 57, 1918-1923. [CrossRef]

138. Li, Q.Y.; Zhang, L.; Xu, Y.X.; Li, Q.; Xue, H.G.; Pang, H. Smart yolk/shell ZIF-67@POM hybrids as efficient electrocatalysts for the oxygen evolution reaction. ACS Sustain. Chem. Eng. 2019, 7, 5027-5033. [CrossRef]

139. Mukhopadhyay, S.; Basu, O.; Kar, A.; Das, S.K. Efficient electrocatalytic water oxidation by Fe(salen)-MOF composite: Effect of modified microenvironment. Inorg. Chem. 2020, 59, 472-483. [CrossRef]

140. Li, S.B.; Zhang, L.; Lan, Y.Q.; O’Halloran, K.P.; Ma, H.Y.; Pang, H.J. Polyoxometalate-encapsulated twenty-nuclear silver-tetrazole nanocage frameworks as highly active electrocatalysts for the hydrogen evolution reaction. Chem. Commun. 2018, 54, 1964-1967. [CrossRef]

141. Zhang, L.; Li, S.B.B.; Gomez-Garcia, C.J.; Ma, H.Y.; Zhang, C.J.; Pang, H.J.; Li, B.N. Two novel polyoxometalate-encapsulated metal-organic nanotube frameworks as stable and highly efficient electrocatalysts for hydrogen evolution reaction. ACS Appl. Mater. Interfaces 2018, 10, 31498-31504. [CrossRef] [PubMed]

142. Fernandes, D.M.; Barbosa, A.D.S.; Pires, J.; Balula, S.S.; Cunha-Silva, L.; Freire, C. Novel composite material polyoxovanadate@MIL-101(Cr): A highly efficient electrocatalyst for ascorbic acid oxidation. ACS Appl. Mater. Interfaces 2013, 5, 13382-13390. [CrossRef] [PubMed]

143. Yan, J.; Zhou, W.Z.; Tan, H.Q.; Feng, X.J.; Wang, Y.H.; Li, Y.G. Ultrafine Ag/polyoxometalate-doped AgCl nanoparticles in metal-organic framework as efficient photocatalysts under visible light. CrystEngComm 2016, 18, 8762-8768. [CrossRef]

144. Chen, D.M.; Liu, X.H.; Zhang, N.N.; Liu, C.S.; Du, M. Immobilization of polyoxometalate in a cage-based metal-organic framework towards enhanced stability and highly effective dye degradation. Polyhedron 2018, 152, 108-113. [CrossRef]

145. Paille, G.; Gomez-Mingot, M.; Roch-Marchal, C.; Lassalle-Kaiser, B.; Mialane, P.; Fontecave, M.; Mellot-Draznieks, C.; Dolbecq, A. A fully noble metal-free photosystem based on cobalt-polyoxometalates immobilized in a porphyrinic metal-organic framework for water oxidation. J. Am. Chem. Soc. 2018, 140, 3613-3618. [CrossRef]

146. Paille, G.; Gomez-Mingot, M.; Roch-Marchal, C.; Haouas, M.; Benseghir, Y.; Pino, T.; Ha-Thi, M.H.; Landrot, G.; Mialane, P.; Fontecave, M.; et al. Thin films of fully noble metal-free POM@MOF for photocatalytic water oxidation. ACS Appl. Mater. Interfaces 2019, 11, 47837-47845. [CrossRef] 
147. Shah, W.A.; Waseem, A.; Nadeem, M.A.; Kogerler, P. Leaching-free encapsulation of cobalt-polyoxotungstates in MIL-100 (Fe) for highly reproducible photocatalytic water oxidation. Appl. Catal. A Gen. 2018, 567, 132-138. [CrossRef]

148. Liang, R.W.; Chen, R.; Jing, F.F.; Qin, N.; Wu, L. Multifunctional polyoxometalates encapsulated in MIL-100(Fe): Highly efficient photocatalysts for selective transformation under visible light. Dalton Trans. 2015, 44, 18227-18236. [CrossRef]

149. He, J.C.; Han, Q.X.; Li, J.; Shi, Z.L.; Shi, X.Y.; Niu, J.Y. Ternary supramolecular system for photocatalytic oxidation with air by consecutive photo-induced electron transfer processes. J. Catal. 2019, 376, 161-167. [CrossRef]

150. Tian, P.; He, X.; Li, W.; Zhao, L.; Fang, W.; Chen, H.; Zhang, F.; Zhang, W.; Wang, W. Zr-MOFs based on Keggin-type polyoxometalates for photocatalytic hydrogen production. J. Mater. Sci. 2018, 53, 12016-12029. [CrossRef]

151. Guo, W.; Lv, H.; Chen, Z.; Sullivan, K.P.; Lauinger, S.M.; Chi, Y.; Sumliner, J.M.; Lian, T.; Hill, C.L. Self-assembly of polyoxometalates, $\mathrm{Pt}$ nanoparticles and metal-organic frameworks into a hybrid material for synergistic hydrogen evolution. J. Mater. Chem. A 2016, 4, 5952-5957. [CrossRef]

152. Zhang, Z.M.; Zhang, T.; Wang, C.; Lin, Z.; Long, L.S.; Lin, W. Photosensitizing metal-organic framework enabling visible-light-driven proton reduction by a Wells-Dawson-type polyoxometalate. J. Am. Chem. Soc. 2015, 137, 3197-3200. [CrossRef] [PubMed]

153. Li, H.; Yao, S.; Wu, H.L.; Qu, J.Y.; Zhang, Z.M.; Lu, T.B.; Lin, W.B.; Wang, E.B. Charge-regulated sequential adsorption of anionic catalysts and cationic photosensitizers into metal-organic frameworks enhances photocatalytic proton reduction. Appl. Catal. B Environ. 2018, 224, 46-52. [CrossRef]

154. Tian, J.; Xu, Z.Y.; Zhang, D.W.; Wang, H.; Xie, S.H.; Xu, D.W.; Ren, Y.H.; Wang, H.; Liu, Y.; Li, Z.T. Supramolecular metal-organic frameworks that display high homogeneous and heterogeneous photocatalytic activity for $\mathrm{H}_{2}$ production. Nat. Commun. 2016, 7, 11580-115808. [CrossRef] [PubMed]

155. Bu, Y.H.; Li, F.Y.; Zhang, Y.Z.; Liu, R.; Luo, X.Z.; Xu, L. Immobilizing CdS nanoparticles and $\mathrm{MoS}_{2} / \mathrm{RGO}_{\text {on }}$ Zr-based metal-organic framework 12-tungstosilicate@UiO-67 toward enhanced photocatalytic $\mathrm{H}_{2}$ evolution. RSC Adv. 2016, 6, 40560-40566. [CrossRef]

156. Borges, M.E.; Diaz, L. Recent developments on heterogeneous catalysts for biodiesel production by oil esterification and transesterification reactions: A review. Renew. Sust. Energ. Rev. 2012, 16, 2839-2849. [CrossRef]

157. Sadakane, M.; Steckhan, E. Electrochemical properties of polyoxometalates as electrocatalysts. Chem. Rev. 1998, 98, 219-237. [CrossRef]

158. Gao, D.D.; Trentin, I.; Schwiedrzik, L.; Gonzalez, L.; Streb, C. The reactivity and stability of polyoxometalate water oxidation electrocatalysts. Molecules 2020, 25, 157. [CrossRef]

159. Kalimuthu, V.S.; Attias, R.; Tsur, Y. Electrochemical impedance spectra of $\mathrm{RuO}_{2}$ during oxygen evolution reaction studied by the distribution function of relaxation times. Electrochem. Commun. 2020, 110, 106641. [CrossRef]

160. Rausch, B.; Symes, M.D.; Chisholm, G.; Cronin, L. Decoupled catalytic hydrogen evolution from a molecular metal oxide redox mediator in water splitting. Science 2014, 345, 1326-1330. [CrossRef]

161. Qin, J.S.; Du, D.Y.; Guan, W.; Bo, X.J.; Li, Y.F.; Guo, L.P.; Su, Z.M.; Wang, Y.Y.; Lan, Y.Q.; Zhou, H.C. Ultrastable polymolybdate-based metal organic frameworks as highly active electrocatalysts for hydrogen generation from water. J. Am. Chem. Soc. 2015, 137, 7169-7177. [CrossRef] [PubMed]

162. Huang, Z.Q.; Luo, Z.; Geletii, Y.V.; Vickers, J.W.; Yin, Q.S.; Wu, D.; Hou, Y.; Ding, Y.; Song, J.; Musaev, D.G.; et al. Efficient light-driven carbon-free cobalt-based molecular catalyst for water oxidation. J. Am. Chem. Soc. 2011, 133, 2068-2071. [CrossRef] [PubMed]

(C) 2020 by the authors. Licensee MDPI, Basel, Switzerland. This article is an open access article distributed under the terms and conditions of the Creative Commons Attribution (CC BY) license (http://creativecommons.org/licenses/by/4.0/). 